CONHEDENTEAL

WAPD-TM-172

AEC RESEARCH AND DEVELOPMENT REPORT

\title{
FURNACE BRAZING OF ZIRCALOY
}

\author{
JANUARY 1959 \\ CONTRACT AT-11-1-GEN-14
}

\section{RESTRICTED/DATA}

This documenf contains restricted data as defined in the Atornd Energy. Act of 1954. Its transmittal or disclosure of its contents in any manner to an unauthorized person is prohibited.

BETTIS PLANT-PITTSBURGH, PA. OPERATED FOR THE U.S. ATOMIC ENERGY COMMISSION BY BETTIS ATOMIC POWER DIVISION, WESTINGHOUSE ELECTRIC CORPORATION 


\section{DISCLAIMER}

This report was prepared as an account of work sponsored by an agency of the United States Government. Neither the United States Government nor any agency Thereof, nor any of their employees, makes any warranty, express or implied, or assumes any legal liability or responsibility for the accuracy, completeness, or usefulness of any information, apparatus, product, or process disclosed, or represents that its use would not infringe privately owned rights. Reference herein to any specific commercial product, process, or service by trade name, trademark, manufacturer, or otherwise does not necessarily constitute or imply its endorsement, recommendation, or favoring by the United States Government or any agency thereof. The views and opinions of authors expressed herein do not necessarily state or reflect those of the United States Government or any agency thereof. 


\section{DISCLAIMER}

Portions of this document may be illegible in electronic image products. Images are produced from the best available original document. 
WAPD-TM-172

C-25: Metallurgy and Ceramics M-3679 (22nd Ed., Rev. I)

\section{FURNACE BRAZING OF ZIRCALOY}

E. R. Slaughter

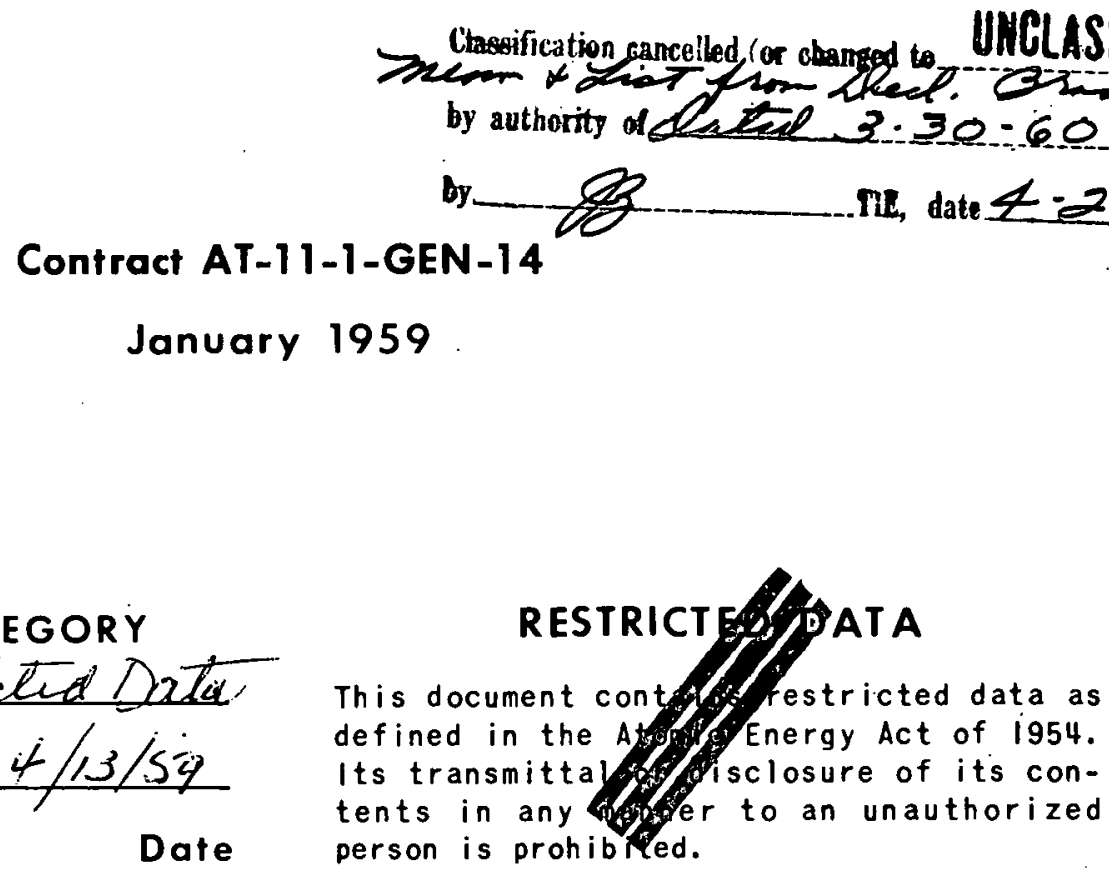

Charge $\$ 0.45$

Available from the U.S. Atomic Energy Commission, Technical Information Service Extension,

P. O. Box 1001, Oak Ridge, Tenn.

Please direct to the same address inquiries covering the procurement of other classifled AEC reports.

Printed in U.S.A.

NOTE

This document is an interim memorandum prepared primarily for internal reference and does not represent a final expression of the opinion of Westinghouse. When this memorandum is distributed externally, it is with the express understanding that Westinghnuse makes no representation as to completeness, accuracy, or usability of information contained therein.

\section{BETTIS PLANT • PITTSBURGH, PA. OPERATED FOR THE U.S. ATOMIC ENERGY COMMISSION BY BETTIS ATOMIC PÓWER DIVISION, WESTINGHOUSE ELECTRIC CORPORATION}




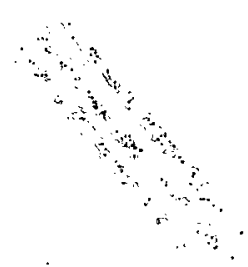

Ihis report was prepared as an account of Government sponsored work. Heithcr the United States, nor the Commission, nor any person acting on bchalf of the rinmmissinn:

A. Makes any warranty or representation, expressed or implied, with respect to the accuracy, completeness, or usefulness of the information contained in this report, or that the use of any information, apparatus, method, or process disclosed in this report may not infringe privately owned rights; or

B. Assumes any liabilities with respect to the use of, or for damages resulting from the use of any information, apparatus, method, or process disclosed in this report.

As used in the above, "person acting on behalf of the commission" includes any employe or contractor of the Commission, or employe of such contractor, to the extent that such employe or contractor of the Commission, or employe of such contractor prepares, disseminates, op provides access to, any information pursuant to his employment or contract with the Commission, or his employment with such contractor. 
TABLE OF CONTENTS

Page No.

SUMMARY

INTRODUCTION

EXPERIMENTAL WORK AND DISCUSSION

Corrosion Resistance of Zircaloy Brazements

Low Melting Range Brazing Alloys

Preparation of Beryllium-Zirconium Brazing Alloy

Effects of Furnace Atmosphere

Preplacing Brazing Alloy

Tensile Strength of Brazed Joints

Dimensional Stability during Brazing 
An experimental investigation was initiated to develop furnace brazing of Zircaloy or Zircaloy-clad nuclear reactor components. The strength and corrosion resistance of brazements were determined and techniques were developed for preplacing the brazing alloy to prevent contamination and to maintain dimensional stability during brazing. Brazements of high strength and adequate dimensional accuracy were produced but the brazing cycles impaired the corrosion resistance of Zircaloy in high-temperature steam and water.

\section{FURNACE BRAZING OF ZIRCALOY}

E. R. Slaughter

\section{SUMMARY}

This investigation was initiated to develop a process for the furnace brazing of Zircaloy-clad nuclear core fuel assemblies. The principal advantage of furnace brazing over a fusion welding process is the elimination of distortion caused by steep thermal gradients inherent in welding.

This investigation showed that furnace brazing could consistently produce high-strength brazements with adequate dimensional tolerances for fuel assemblies. Zircaloy which was subjected to a brazing cycle followed by slow cooling was, however, less corrosion resistant than untreated Zircaloy.

Zircaloy slow cooled from the brazing temperature had weight gains $45 \%$ greater than those of untreated Zircaloy in $140^{\circ}$-day, $680^{\circ} \mathrm{F}$ water-phase corrosion tests and much larger weight gains in $110-$ day, $750^{\circ} \mathrm{F}$ Eteam corrosion tests, Postahrazing thermal treatments failed to improve the corrosion resistance.

Since slow cooling through the alpha plus beta range caused the poor corrosion resistance of brazed Zircaloy, the problem of corrosion resistance could be avoided by lowe ring the brazing temperature. The addition of 10 to $13 \%$ iron to a Zircaloy-beryllium brazing alloy lowered the liquidus temperature from $1830^{\circ} \mathrm{F}$ to approximately $1535^{\circ} \mathrm{F}$ and offered a possible solution to the problem of poor corrosion resistance.

Strength of simulated fuel plate to side plate joints was a function of the joint clearance and thermal history. Tensile specimens, which had small joint clearances and had been subjected to a diffusion-promoting brazing cycle, fractured away from the brazed joints in a ductile manner. Lower strengths and brittle fractures occurred in tensile specimens which had a nearly continuous beryllium-rich phase in the joints. Larger joint clearances increased the amounts of the berylliumrich phase retained in the joints. 
Atmospheric contamination during brazing impaired the flow characteristics of the brazing alloy. The vacuum ordinarily obtained in a production vacuum annealing furnace was inadequate to protect the brazing alloy, but adequate protection from contamination was obtained consistently by simple procedures for improving the vacuum.

A method of preplacing the brittle brazing alloy was based upon the exceptional capillarity of the brazing alloy. Brazements were designed to have one or more continuous networks of capillary joints to be brazed. These brazements were brazed by the capillary flow from one or more relatively large pieces of the brazing alloy. The brazing alloy flowed upward against the force of gravity as much as $30 \mathrm{in}$. by capillary action. The reliability of this method for small brazements was demonstrated by the brazing of 6 brazements with 8 vertical joints, each with no unbrazed joints.

A method for using small, reusable graphite spacers to maintain coolant channel thickness during brazing showed promise of controlling this dimension within acceptable limits.

\section{INTRODUCTION}

Furnace brazing of Zircaloy or Zircaloy-clad components possesses certain advantages over fusion welding in the assembly of nuclear core assemblies. Furnace brazing and fusion welding are compared as follows:

\section{Furnace Brazing}

1) Furnace brazing causes no significant thermal gradients.

2) Inaccessible joints are readily brazed.

3) There are no limitations on thickness of sections joined.

4) Many joints may be brazed simultaneously.
Finsinn Walding

1) Steep thermal gradients cause shrinkage and distortion during fusion welding.

2) Joints must be accessible for welding.

3) The practical upper limit on the thickness of sections which can be fusion welded is approximately 0.2 inches.

4) Fusion welding is a progressive operation.

A previous study was made to develop corrosion resistant brazing alloys for Zircaloy (Ref 1 ). Several corrosion resistant brazing alloys were developed, but alloys containing 4 to $6 \%$ beryllium and 94 to $96 \%$ Zircaloy were determined to have the best combination of corrosion resistance, melting point, strength, flow characteristics, and absence of erosive action on the base material. A nominal composition of 5\% beryllium-95\% Zircaloy-2 was chosen as the brazing alloy for this investigation. Although beryllium and certain of its compounds are extremely toxic (Ref 2$)$, the proper precautions should allow the handling of beryllium alloys safely.

Although an apparently satisfactory brazing alloy had been developed for Zircaloy, it was anticipated that major problems would be encountered if this alloy were used to furnace-braze nuclcar core assemblies. The major anticipated problems were: (1) maintaining the corrosion resistance of Zircaloy cladding after brazing, (i) obtaining adequate mechanical properties of brazed joints, (3) preplacing the brittle brazing alloy, and (4) maintaining critical dimensions.

\section{EXPERIMENTAL WORK AND DISCUSSION}

\section{Corrosion Resistance of Zircaloy Brazements}

The thermal history of Zircaloy-2 affects its corrosion resistance in high-temperature water and steam. Since the major application for brazing of nuclear core components would be assemblies whose geometry and size would prevent their being cooled rapidly by convection and radiation from their exterior surfaces, slow cooling of at least the central regions of these assemblies must be expected. 
The effect of slow cooling from high temperatures upon the corrosion resistance of Zircaloy-2 has been investigated. Early work (Ref 3) showed that the weight gain of Zircaloy-2 in long-term steam and water corrosion tests increased with increasing annealing temperatures in the range from $1475^{\circ}$ to $1850^{\circ} \mathrm{F}$, but these data indicated no important effect of cooling rate upon corrosion resistance. However, the data of a recent investigation (Ref 4) showed a cooling-rate dependence of the corrosion resistance, but little dependence on the annealing temperature in the range from $1450^{\circ}$ to $1850^{\circ} \mathrm{F}$ for rapidly-cooled specimens. Weight gains of specimens slowly cooled from $1850^{\circ} \mathrm{F}$ were increased by a factor of roughly three over specimens annealed at $1450^{\circ} \mathrm{F}$. It was shown that a minimum cooling rate of $90^{\circ} \mathrm{F} / \mathrm{min}$ through the range from $1850^{\circ}$ to $1472^{\circ} \mathrm{F}$ is sufficient to obtain acceptable weight gains.

Poor corrosion resistance of Zircaloy brazements resulting from slow cooling from brazing temperature was anticipated. Four possible solutions were considered: (1) thermal treatments after brazing, (2) use of a lower-melting-range brazing alloy, (3) induction brazing to localize high temperatures and permit rapid cooling, and (4) inert gas quenching from brazing temperature.

Induction brazing and inert gas quenching were rejected as possible solutions. Induction brazing would introduce steep thermal gradients and require accessibility to the joints, thereby losing the principal advantages of furnace brazing. Quenching by forced convection of an inert gas through the coolant passages of brazed nuclear components. would require excessive amounts of equipment and development effort. An adequate mass flow of an inert gas through a typical nuclear component could be attained at reasonable gas velocities only by pressurizing the furnace to a relatively high pressure (several hundred pounds per square inch). Gas quenching would also introduce thermal gradients and possible distortion.

The possibility of improving the corrosion resistance by thermal treatment was based upon the hypothesis that the poor corrosion resistance of slow-cooled Zircaloy- 2 is caused by partitioning effects during cooling through the alpha plus beta range (approximately $1850^{\circ}$ to $1475^{\circ} \mathrm{F}$ ). Alloying elements and impurity atoms have different solubilities in alpha and beta zirconium. The partitioning of such elements between co-existing alpha and beta would depend upon the relative amounts of the phases, solubilities of such elements in both phases, and time. Hence, the cooling rate through the two-phase region would affect the composition of regions. The regions which transformed last would be depleted in alpha-soluble elements and enriched in beta-soluble elements. If such an alloy were subsequently maintained for prolonged periods at a high temperature within the alpha range, homogenization would occur, and, hence, the corrosion resistance might be restored.

Three thermal treatments were used in the study of the effect of thermal treatments on the corrosion resistance of slow-cooled Zircaloy- 2 brazements. The treatments will be hereafter termed: (1) slow-cooled treatment, (2) alpha-annealed treatment, and (3) two-phase annealed. Comparison of the corrosion resistance of slow-cooled and alpha-annealed brazements was expected to establish whether homogenization treatments in the alpha range would improve the corrosion resistance of slow-cooled Zircaloy-2. The two-phase annealed brazement, which was homogenized in the high beta and alpha field $\left(1750^{\circ} \mathrm{F}\right)$, was included in the corrosion study since it was known that dispersivn of berylliun frum juints by diffusion inproved ine chanicical properties.

The corrosion specimens were prepared from an ingot of atmosphere-melted, reactor-grade Zircaloy-2 (FU120). The design of the brazement and corrosion coupons is shown in Fig. 1 . The surfaces of the dummy fuel plates were in the cold-rolled and pickled condition, but the side plates were fabricated by machining $0.025 \mathrm{in}$. or more from the surfaces of hot-rolled bar.

Prior to brazing, the components of the brazements were scrubbed with a detergent (Alconox), rinsed in hot tap water, immediately wiped with cloth saturated in acetone, and finally wiped with cloth saturaled with absolute ethyl alcohol. 


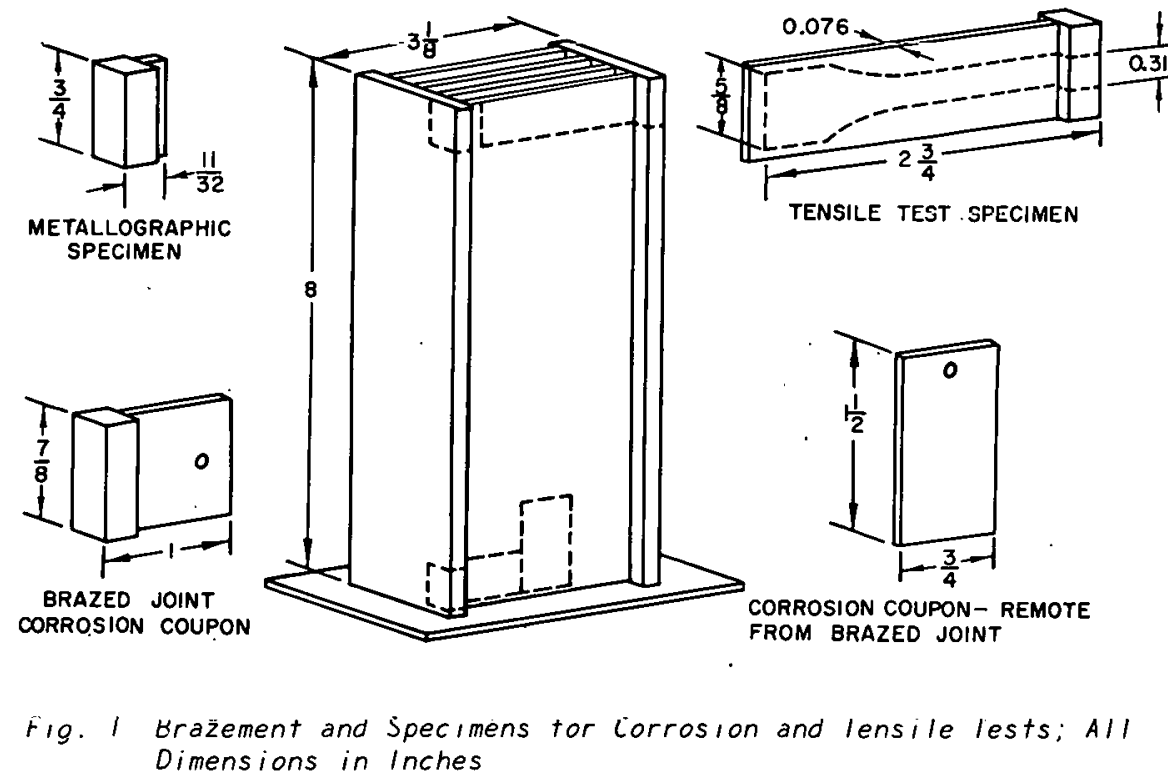

The components were assembled, as shown in Fig. 1, and secured by strips of Zircaloy (not shown) tack welded between the side plates. A single piece of brazing alloy weighing approximately 7 grams was placed at the bottom of the center channel. The brazing alloy used was prepared by the Zircaloy-crucible melting procedure which will be discussed in a later section. The precautions taken to secure a protective atmosphere (high vacuum) will also be discussed in a later section.

The brazements were subjected to three thermal cycles:

1) Slow cooled-This cycle consisted of brazing at $1832^{\circ} \mathrm{F}$ for $1 \mathrm{hr}$ and slow cooling $\left(75^{\circ} \mathrm{F} / \mathrm{hr}\right)$ to $1300^{\circ} \mathrm{F}$. The cooling rate below $1300^{\circ} \mathrm{F}$ was believed to be unimportant. Therefore, when the temperature reached $1300^{\circ} \mathrm{F}$, the brazements were moved to the cold zone in all three cycles.

2) Alpha annealed-This cycle consisted of brazing at $1832^{\circ} \mathrm{F}$ for $1 \mathrm{hr}$, slow cooling $\left(75^{\circ} \mathrm{F} / \mathrm{hr}\right)$ to $1427^{\circ} \mathrm{F}$, holding at that temperature for $16 \mathrm{hr}$, and slow cooling from $1427^{\circ}$ to $1300^{\circ} \mathrm{F}$.

3) Two-phase annealed-This cycle consisted of brazing at $1832^{\circ} \mathrm{F}$ for $1 \mathrm{hr}$, slow cooling $\left(75^{\circ} \mathrm{F} /\right.$ $\mathrm{hr})$ to $1750^{\circ} \mathrm{F}$, holding at that temperature for $8 \mathrm{hr}$, slow cooling $\left(75^{\circ} \mathrm{F} / \mathrm{hr}\right)$ to $1410^{\circ} \mathrm{F}$, holding at that temperature for $8 \mathrm{hr}$, and slow cooling from $1410^{\circ}$ to $1300^{\circ} \mathrm{F}$.

Corrosion coupons were machined from three brazements for a factorial corrosion experiment to include four factors at the levels indicated:

1) Coupons including brazed joints and coupons remote from brazed joints,

2) The three thermal treatments-slow cooled, alpha annealed, and two-phase annealed,

3) $750^{\circ} \mathrm{F}, 1500 \mathrm{psi}$ steam corrosion tests and $680^{\circ} \mathrm{F}$ water-phase corrosion tests, and

4) Specimens plckled aftër bräıng and specımens not pickled after brazing.

'l'riplicate specimens were used for each condition. Control specimens of the untreated Zircaloy (FU120) were also included.

The results of these corrosion tests are shown in Table I and Figs. 2 and 3. Photographs of the specimens are shown in Figs. 4 through 7.

Weight gains of unpickled specimens were all substantially greater $\left(100\right.$ to $\left.600 \mathrm{mg} / \mathrm{dm}^{2}\right)$ than the corresponding pickled corrosion coupons after the first cycle of 14 days in steam or 28 days in 
TABLE I

WEIGHT GAIN (mg/dm ${ }^{2}$ ) OF BRAZED ZIRCALOY-2 JN STEAM AND WATER CORROSION TESTS

\begin{tabular}{|c|c|c|c|c|c|c|c|c|c|c|c|}
\hline \multirow{2}{*}{ Condition } & \multicolumn{6}{|c|}{ Steam Corrosion Tests $-750^{\circ} \mathrm{F} 1500$ psi } & \multirow{2}{*}{\multicolumn{5}{|c|}{ Water Corrosion Tests $-680^{\circ} \mathrm{F}$ Seturation Pressure }} \\
\hline & 14 days & 28 days & 56 days & 84 days & 112 days & 140 days & & & & & \\
\hline Braze joint & 175 & 212 & 253 & 316 & * & -- & 26 & 33 & 64 & 72 & 85 \\
\hline Remote from joint & 172 & 199 & 312 & 347 & * & -- & 25 . & 31 & 54 & 65 & 75 \\
\hline \multicolumn{12}{|l|}{ Alpha-annealed } \\
\hline Braze joint & 184 & 230 & 270 & 318 & * & -- & 29 & 37 & 71 & 80 & 95 \\
\hline Remote from joint & 177 & 222 & 286 & 337 & * & -- & 25 & 31 & 58. & 67 & 82 \\
\hline Remote from joint & 266 & 311 & 356 & * & - & -- & 26 & 41 & 93 & 107 & 123 \\
\hline \multicolumn{12}{|l|}{ Hot-rolled Zircaloy } \\
\hline (not brazed) & 31 & 36 & 68 & 96 & 120 & 143 & 22 & 29 & 35 & 42 & 56 \\
\hline
\end{tabular}




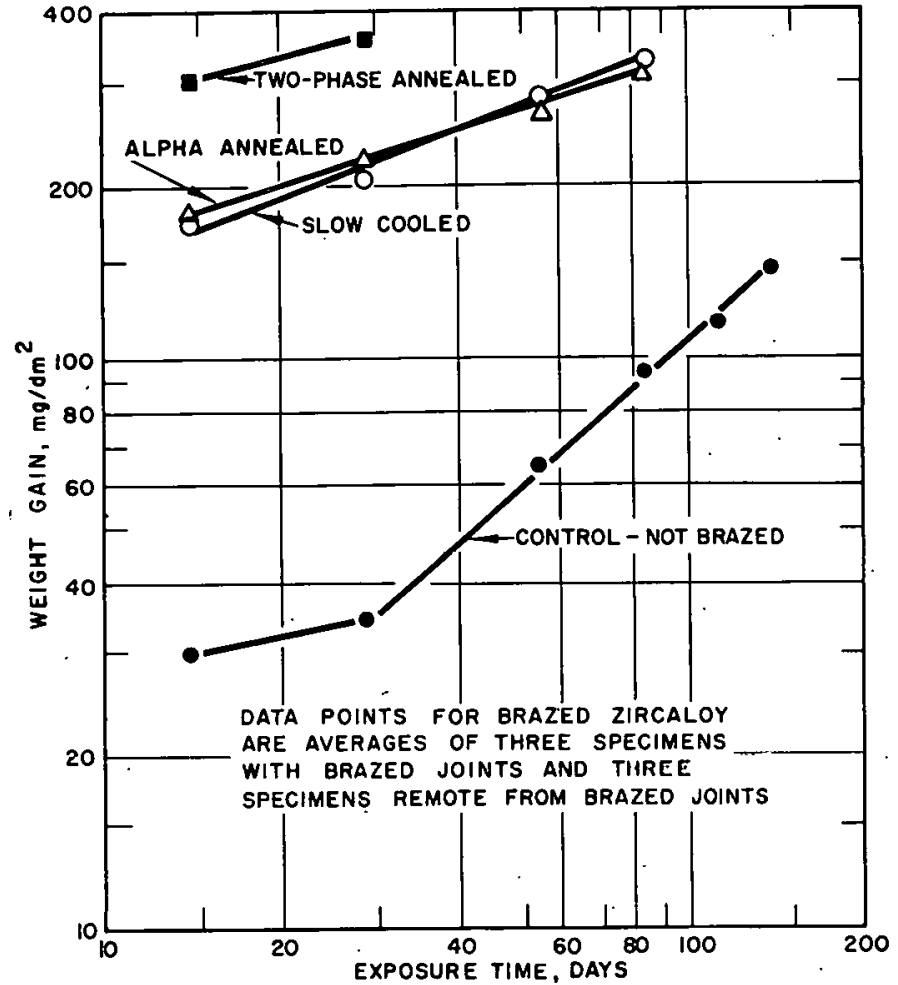

Fig. 2 Weight Gain of Brazed Zircaloy in $750^{\circ} \mathrm{F}$ Steam

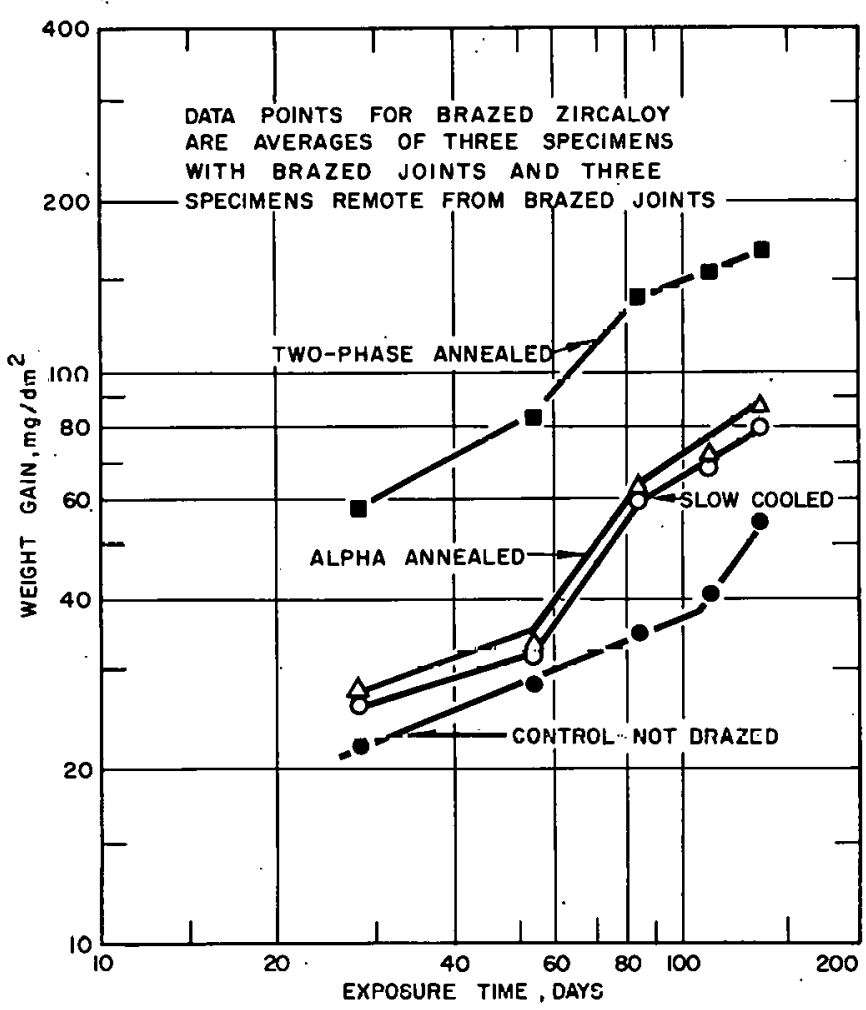

Fig. 3 Weight Gain of Brazed Zircaloy in $680^{\circ} \mathrm{F}$ Water water. Weight gains of the unpickled specimens were not included in Table $I$, as they were believed to be inaccurate due to spalling of corrosion products dur ing the first corrosion test cycle. It was noted that those surfaces of the unpickled coupons which were machined after brazing appeared to have more nearly normal corrosion films than the surfaces exposed to the furnace atmosphere (Figs. 4 and 5). Thus, the corrosion resistance was apparently lowered by contamination of the surfaces during brazing. Such contamination could have been caused by the furnace atmospherc or by residues reinainitig on the susfaces when clearled. This contamination must have been at least partially removed when 0.001 to 0.002 in. was removed from each surface by pickling, since the pickled coupons exhibited better corrosion resistance.

The corrosion films were thicker at the brazed joints than in areas remote from brazed joints, as indicated by their appearance and by larger weight gains. After 28 days in $680^{\circ} \mathrm{F}$ water, for example. the brazed joints of pirkted collpons exhibited a yellowish-brown adhercnt corrosion product, while surfaces remote from the brazcd joints had a lustrous black film (Fig. 4). The two-phase annealing treatment accentuated the effect of the brazed joints on the corrosion resis tance (Fig. 5). Since the area of the hrazing allny exposed was only 2 small fraction of the total area, the effects of the brazed joints on the weighl gains were largcly obscurcd. Therefore; the signifi= cantly higher weight gains observed for the brazed joint specimens indicated that brazed joints had a pronounced effect on the corrosion resistance. While the corrosion resistance of the brazed joints was inferior to that of Zircaloy remote from brazed joints, there was no penetration of corrusive attack into brazed joints after 140 days. in $680^{\circ} \mathrm{F}$ water. 

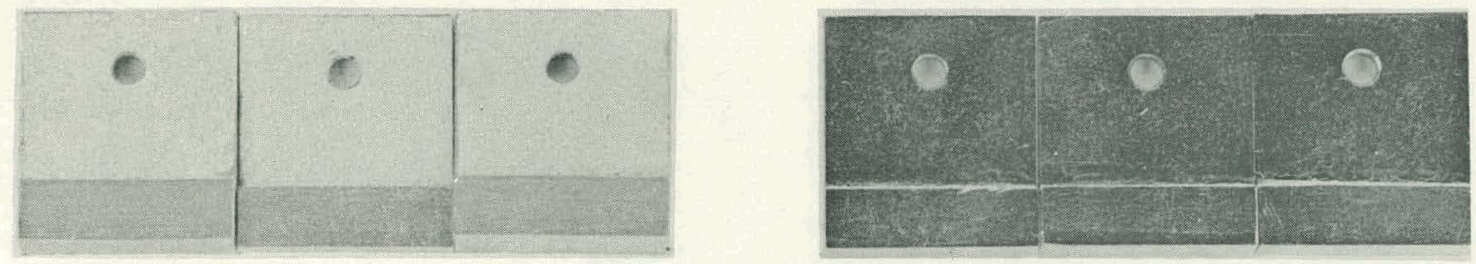

BRAZED JOINT
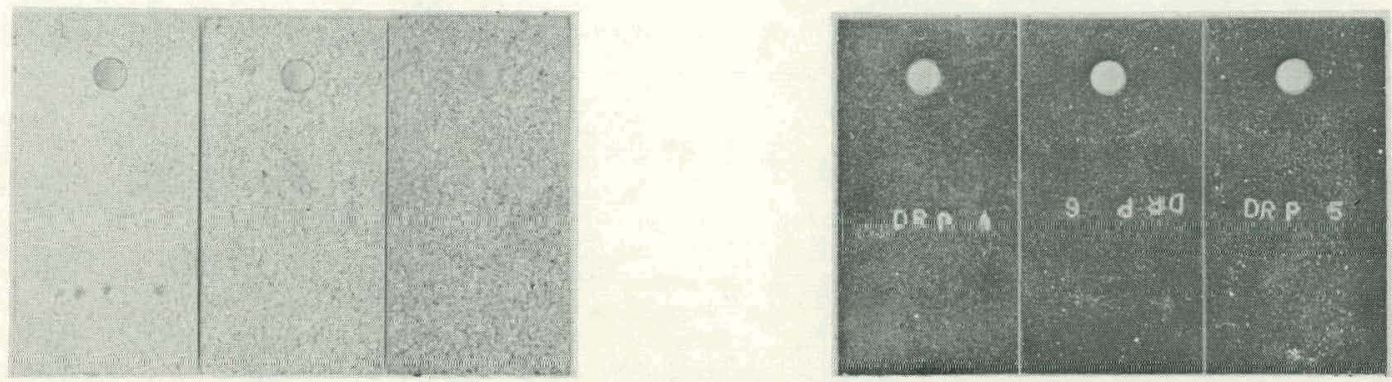

REMOTE FROM BRAZED JOINTS

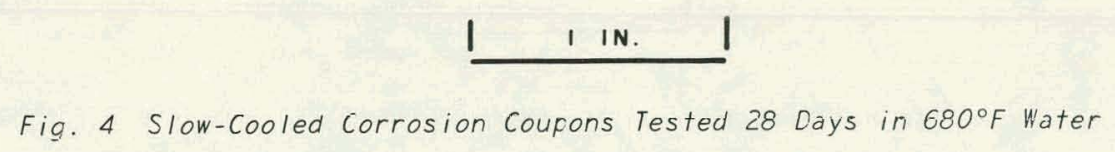

All brazing cycles used caused large increases in the weight gains of Zircaloy-2 in $750^{\circ} \mathrm{F}$ steam corrosion tests (Fig. 2). The weight gain of Zircaloy which was subjected to a brazing cycle was, in general, 3 to 10 times as large as that of the untreated Zircaloy. In the steam corrosion tests, the alpha-annealed and the slow-cooled treatments produced essentially identical behavior, while the two-phase annealed treatment had the largest weight gains.

After the first 14-day cycle in the steam corrosion test, the corrosion coupons of brazed Zircaloy exhibited flecks of a yellowish-brown corrosion product (Fig. 6). As the corrosion tests continued, this corrosion product increased to form a nearly continuous layer and began to spall after 28 to 84 days of corrosion testing.

In $680^{\circ} \mathrm{F}$ water corrosion tests, as in the steam corrosion tests, the brazing cycles caused increases in the weight gains of Zircaloy. The two-phase annealed treatment caused the largest increases in weight gains while the alpha-annealed treatment consistently produced slightly larger weight gains than did the slow-cooled treatment.

After 28 days in $680^{\circ} \mathrm{F}$ water, flecks of the yellowish-brown corrosion product were not visible on the slow-cooled and alpha-annealed coupons (Fig. 4). After 140 days in $680^{\circ} \mathrm{F}$ water, the slowcooled and alpha-annealed coupons were flecked with this corrosion product (Fig. 7), while the twophase annealed coupons were coated almost continuously.

\section{Low Melting Range Brazing Alloys}

The most desirable solution to the corrosion problem would be the development of a corrosion resistant brazing alloy with a melting range below the transition temperature of Zircaloy, but the 

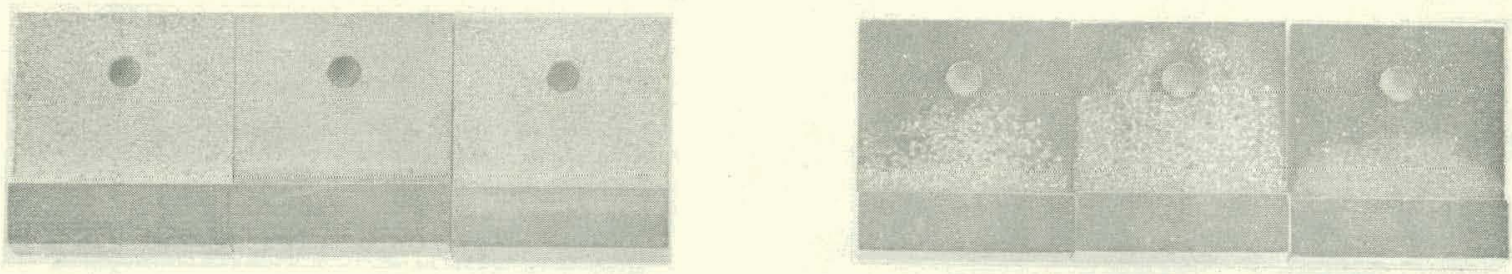

BRAZED JOINT
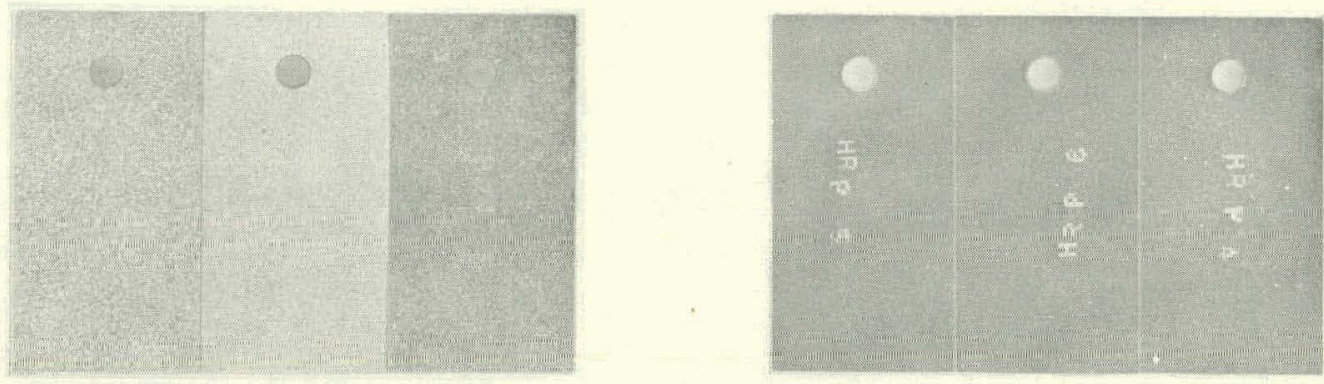

REMOTE FROM BRAZED JOINTS

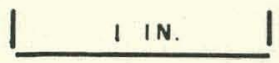

Fig. 5 Two-Phase Annealed Corrosion Coupons Tested 28 Days in $680^{\circ} \mathrm{F}$ Water

development of a corrosion resistant brazing alloy melting in the lower portion of alpha plus beta range of Zircaloy might be more likely. Slow cooling from the lower portions of the alpha plus beta range is reported (Ref 4) to cause small increases in weight gains of Zircaloy-2 in $750^{\circ} \mathrm{F}$ steam corrosion tests when compared to the untreated material, while much larger increases in weight gains are caused by slow cooling from $1650^{\circ} \mathrm{F}$ and higher temperatures. Thus, a brazing alloy with a melting range in the lower portion of the alpha plus beta range of Zircaloy may be acceptable.

During the development of the zirconium-beryllium brazing alloys (Ref 1), many brazing alloys were screened for corrosion resistance in a $1200 \mathrm{hr}$ test in $680^{\circ} \mathrm{F}$ water. Some zirconium-based brazing alloys containing iron showed promising corrosion resistance. An assembly brazed with an $80 \% \mathrm{Zr}-10 \% \mathrm{Fe}-10 \% \mathrm{Cr}$ alloy was unattacked in $1235 \mathrm{hr}$ in $680^{\circ} \mathrm{F}$ water, and assemblies brazed with an $80 \% \mathrm{Zr}-10 \% \mathrm{Sn}-10 \% \mathrm{Fe}$ and a $70 \% \mathrm{Zr}-15 \% \mathrm{Fe}-15 \% \mathrm{Mn}$ alloy showed only moderate attack in $1200 \mathrm{hr}$.

Since the binary eutectic of iron with zirconium has a lower melting point than that of beryllium with zirconium, the addition of iron to beryllium-zirconium alloys might be expected to lower their melting range and perhaps retain adequate corrosion resistance.

A series of zirconium-base alloys were prepared by nonconsumably arc melting 50 buttons in an inert gas atmosphere. The nominal compositions of these alloys and a crude approximation of the amounts of liquid phase formed at several temperatures are presented in Table II.

From these data, it appeared that the alloys containing $4 \%$ beryllium, $10 \%$ or $13 \%$ iron, and balance Zircaloy-2 have narrow melting ranges which are low enough to be of interest for brazing alloys. These and other similar alloys are being evaluated by Bettis Plant. 
TABLE II

NOMINAL COMPOSITIONS AND APPROXIMATE MELTING RANGES OF EXPERIMENTAL BRAZING ALLOYS

\begin{tabular}{|c|c|c|c|c|c|c|c|c|c|c|c|c|c|}
\hline \multirow[b]{2}{*}{ Identification } & \multicolumn{5}{|c|}{ Nominal Composition, $\%$} & \multicolumn{8}{|c|}{ Approximate Amount of Liquid Phase, \% } \\
\hline & $\mathrm{Be}$ & $\mathrm{Fe}$ & $\mathrm{Cu}$ & $\mathrm{Cr}$ & ZircaIoy -2 & $1472^{\circ} \mathrm{F}$ & $1490^{\circ} \mathrm{F}$ & $1515^{\circ} \mathrm{F}$ & $1535^{\circ} \mathrm{F}$ & $1560^{\circ} \mathrm{F}$ & $1610^{\circ} \mathrm{F}$ & $1650^{\circ} \mathrm{F}$ & $1695^{\circ} \mathrm{F}$ \\
\hline B554 & 5 & 5 & -- & -- & 90 & 0 & 0 & 10 & -- & 10 & - & 25 & 25 \\
\hline B555 & 5 & 10 & -- & -- & 85 & 0 & 0 & 10 & -- & 75 & 100 & 100 & 100 \\
\hline B556 & 7 & 5 & -- & -- & 88 & 0 & 0 & 10 & -- & 10 & 10 & 10 & 10 \\
\hline B557 & 7 & 10 & -- & -- & 83 & 0 & 0 & 10 & -- & 10 & -- & 25 & 100 \\
\hline B558 & $T$ & 5 & 5 & -- & 83 & 0 & 10 & 10 & -- & 10 & 10 & 50 & 75 \\
\hline B559 & 5 & 3 & 3 & -- & 89 & 0 & 10 & 10 & -- & 10 & 10 & 25 & 75 \\
\hline B569 & 4 & 7 & -- & -- & 89 & -- & -- & -- & 10 & 10 & -- & -- & -- \\
\hline B570 & 4 & 10 & -- & -- & 86 & -- & -- & -- & 100 & 100 & -- & -- & -- \\
\hline B571 & 4 & 13 & - & -- & 83 & -- & -- & -- & 100 & 100 & -- & -- & -- \\
\hline B572 & 4 & 5 & -- & 5 & 91 & - & -- & -- & 10 & 75 & -- & -- & -- \\
\hline B573 & 6 & 7 & -- & -- & 87 & -- & - & -- & 10 & 10 & -- & -- & -- \\
\hline B574 & 6 & 10 & -- & -- & 84 & -- & -- & -- & 10 & 10 & -- & -- & -- \\
\hline B575 & $\dot{b}$ & 13 & -- & -- & 81 & -- & -- & - & 25 & 25 & -- & -- & -- \\
\hline B576 & í & 5 & -- & 5 & 84 & -- & -- & -- & 10 & 10 & -- & -- & -- \\
\hline
\end{tabular}



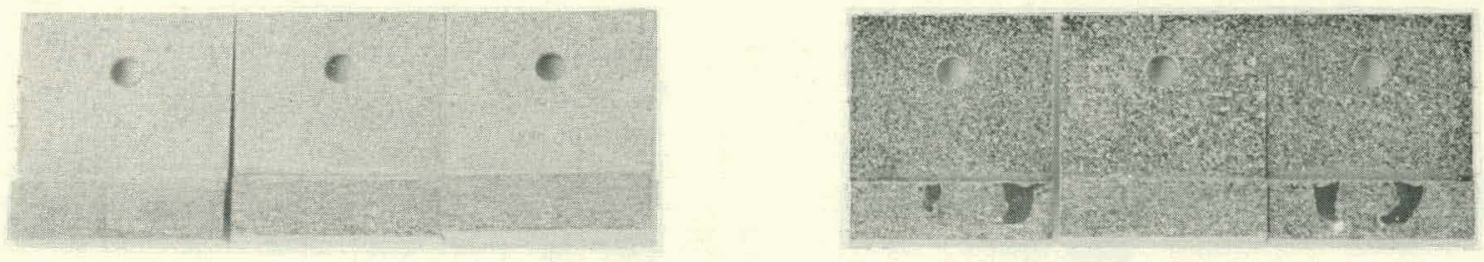

BRAZED JOINT
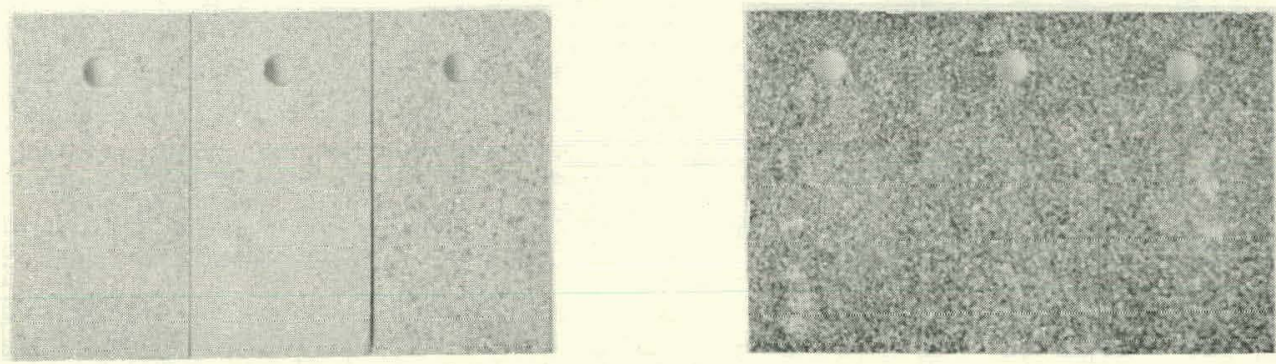

REMOTE FROM BRAZED JOINTS

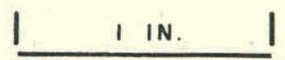

Fig. 6 Slow-Cooled Corrosion Coupons Tested 14 Days in $750^{\circ} \mathrm{F}$ Steam

The structures of "thick" and "thin" portions of a joint brazed $1 \mathrm{hr}$ at $1560^{\circ} \mathrm{F}$ with $5 \%$ Be $-10 \%$ Fe $-85 \%$ Zircaloy brazing alloy are shown in Figs. 8a and 8b.

\section{$\underline{\text { Preparation of Beryllium-Zirconium Brazing Alloy }}$}

During the development of Zircaloy-beryllium brazing alloys (Ref 1), the preparation of alloys by nonconsumably arc melting small buttons presented no problems. However, the preparation of larger amounts of Zircaloy-beryllium alloys presented problems in obtaining homogeneous alloys with the nominal melting range.

Preparation of the $5 \% \mathrm{Be}-95 \%$ Zircaloy-2 brazing alloy by induction melting in a berylliawashed graphite crucible produced an alloy with a substantially higher melting range than that reported for arc-melted buttons of the identical nominal composition (melting range approximately $1780^{\circ}$ to $1813^{\circ} \mathrm{F}$ ). During brazing experiments the induction-melted alloy was only partially melted at the maximum operating temperature $\left(1900^{\circ} \mathrm{F}\right)$ of the available heat treating furnace. This high melting range was judged to be a serious disadvantage; therefore, other melting practices werc used to obtain a low melting range alloy.

Combinations of nonconsumable arc melting and consumable electrode melting left significant amounts of unmelted Zircaloy feed particles in a matrix of Be-enriched alloy. Spectrographic analysis indicated that the Be-enriched portion contained from 5.9 to $6.6 \% \mathrm{Be}$. The failure of these melting operations to dissolve all of the Zircaloy probably resulted from a combination of two factors. The density of the liquid phase was less than the density of Zircaloy, thereby allowing the Zircaloy particles to settle to the cool, lower portions of the molten pool. Also, there was a large difference between the melting ranges of Zircaloy and the Be-Zircaloy alloy. 

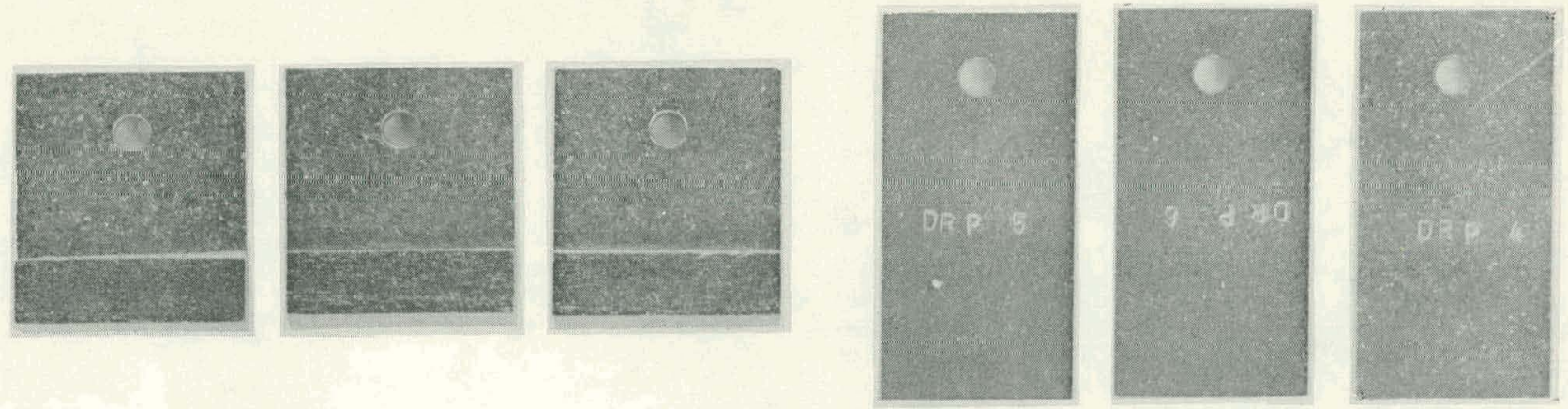

CONTROL - NOT BRAZED
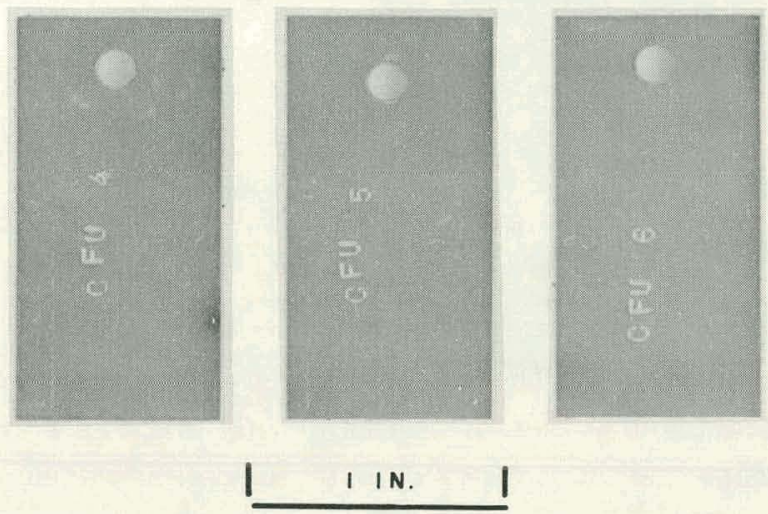

Fig. 7 Slow-Couled Corrosion Coupons Tested 140 Days in $680^{\circ} \mathrm{F}$ Water

A homogeneous brazing alloy of approximately eutectic composition was obtained by remelting an ingot produced by nonconsumable-electrode arc melting to dissolve or settle the undissolved Zircaloy particles. The remelting was accomplished in a Zircaloy crucible in a vacuum furnace at $1832^{\circ} \mathrm{F}$ for $2 \mathrm{hr}$. The brazing alloy was allowed to solidify in the crucible and then was removed by sectioning the mass. The liquidus temperature of this alloy was approximately $1832^{\circ} \mathrm{F}$ and spectrographic analysis indicated a beryllium content of $4.3 \%$. However, this material was porous near the center of the mass because of solidification shrinkage.

An improved method of preparing Zircaloy-Be alloys was developed by Bettis Plant. A laminated electrode for consumable melting was prepared by tack welding a rod of beryllium to Zircaloy strips so that a cross section contained the correct proportions of Zircaloy and beryllium. A sound ingot, weighing two pounds, was produced by arc melting this electrode consumably in a watercooled copper crucible. The macro etching of a longitudinal section revealed no evidence of segregation. The Zircaloy - 5\% Be brazing alloy used during the final phases of this investigation was prepared in this manner.

\section{Effects of Furnace Atmosphere}

The reactivity of Zircaloy with common gases at elevated temperatures dictated the use of either a noble gas or a high vacuum during brazing. The use of vacuum throughout this investigation was based upon the possibility that an inert gas could be trapped in joints and prevent the entry of brazing alloy.

The greater portion of the brazing reported in this investigation was accomplished in a relatively large (18-in. diam by 7 -ft long hot zone) vertical annealing furnace used for production 


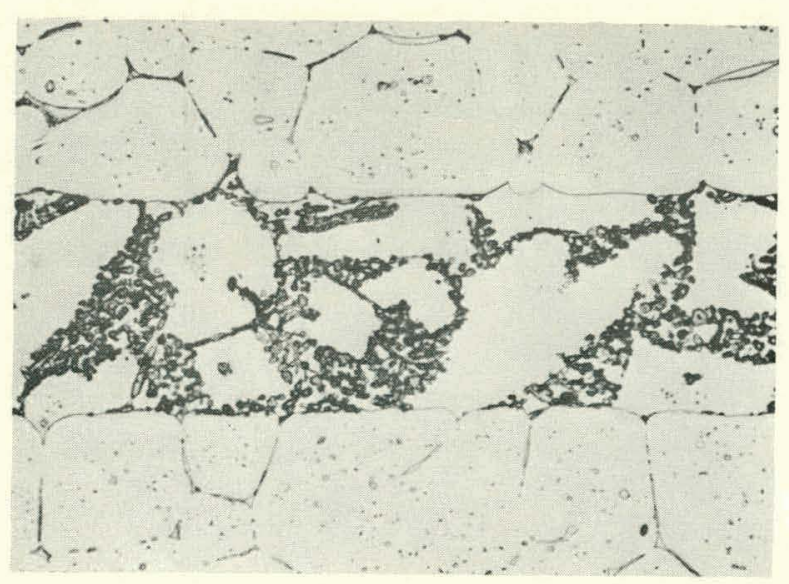

a Thirk Inint structure

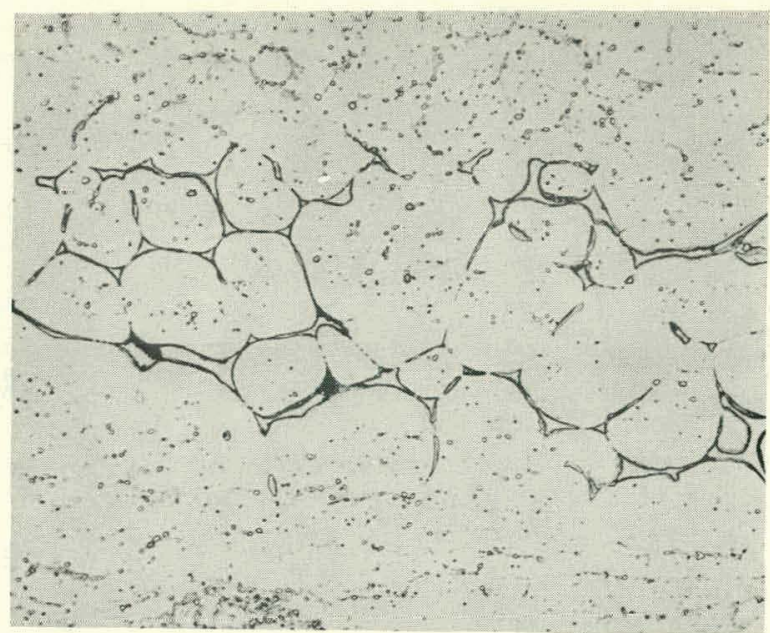

b. Thin joint Structure

Fig. 8 Structures of Joints Brazed with a $5 \%$

Beryllium, 10\% Iron, and 85\% Zircaloy

Brazing Alloy; Both Structures 250x

annealing of nuclear core components. The vacuum gages on this furnace were close to the diffusion pump and the radiation shields, and piping offered relatively high resistance to the molecular flow of gases between the vacuum gage and the furnace retort. Thus, the vacuum gage did not give a reliable indication of pressure within the furnace retort. The observed pressure readings varied little for various furnace charges, although varying contamination of the Zircaloy indicated considerable differences in the degree of vacuum. The observed pressures were typically less than $0.03 \mathrm{microns}$ prior to heating and during cooling, but rose to approximately 0.1 to 0.2 microns as the brazing temperature was attained. 'The effects of the furnace atmosphere can be discussed most rationally in terms of the appearance of the Zircaloy and brazing alloy as affected by various procedures.

The furnace atmosphere, rather than residues on the surface of the Zircaloy from the cleaning operation, was the principal source of contamination. This fact was estahlished hy nhserving the effect of the geometry of the specimen upon the films formed on the Zircaloy.

At elevated temperatures, gaseous corrosion films dissolve in Zircaloy and, if the rate of solution exceeds the rate of formation, a metallic luster is maintained throughout a heating cycle. If the rate of formation is increased to exceed the rate of solution, a corrosion film is formed during the heating cycle. Throughout this investigation, Zircaloy surfaces, which formed the interior surfaces of nearly enclosed cavities in Zircaloy, exhibited a more metallic luster than did the exterior surfaces of Zircaloy specimens which were exposed directly in the furnace retort without the protection of any gettering action. If the source of the contamination were residues upon the surface of the Zircaloy, recesses would have surfaces contaminated at least as badly as exposed surfaces. Since this was not true, the furnace atmosphere must have been the source of contaminants.

Graphite fixtures were employed to prevent eutectic formation between Zircaloy and ferrous furnace hardware. Zircaloy surfaces in contact with outgassed graphite maintained lustrous metallic surfaces.

There were four general types of procedures used to prevent contamination during brazing. These are listed in order of increasing effectiveness: 
1) A large furnace retort with a small charge of Zircaloy was evacuated and immediately heated to brazing temperature.

2) A large furnace retort with a small charge of Zircaloy was evacuated for extended periods (as much as $16 \mathrm{hr}$ ) and heated for brazing.

3) A small charge of Zircaloy was placed within a small graphite retort with Zircaloy gettering strips, and the graphite retort was placed in the large furnace retort. Then, the furnace was evacuated for $16 \mathrm{hr}$ prior to heating.

4) This procedure differed from the third procedure in that evacuating the furnace to approximately 5 microns pressure, backfilling with an inert gas to approximately atmospheric pressure, and evacuating briefly was substituted for the extended evacuation cycle.

The third and fourth procedures produced approximately equivalent results.

The flow of the brazing alloy was affected by the purity of the atmosphere. Although there was a continuous gradation of effects from the highest purity atmosphere observed (highest vacuum) to the lowest purity atmosphere (poorest vacuum), it is convenient to discuss these effects for three arbitrarily selected conditions. For convenience these will be termed "best," "good," and "poor" atmospheres; although, no quantitative measure of pressure can be ascribed to them.

Under the influence of the best atmosphere, the brazing alloy wet the Zircaloy at a very small angle and showed a pronounced tendency to seek capillary joints. The capillarity of the brazing alloy under the best conditions was measured and will be discussed in a later section. Figure $9 \mathrm{a}$ shows a fillet of brazing alloy which exhibited a very small angle of contact.

Under the influence of a good atmosphere, the brazing alloy wet the Zircaloy at a greater contact angle than under the best conditions (Fig. 9b). The brazing alloy showed a strong tendency to seek capillary joints.

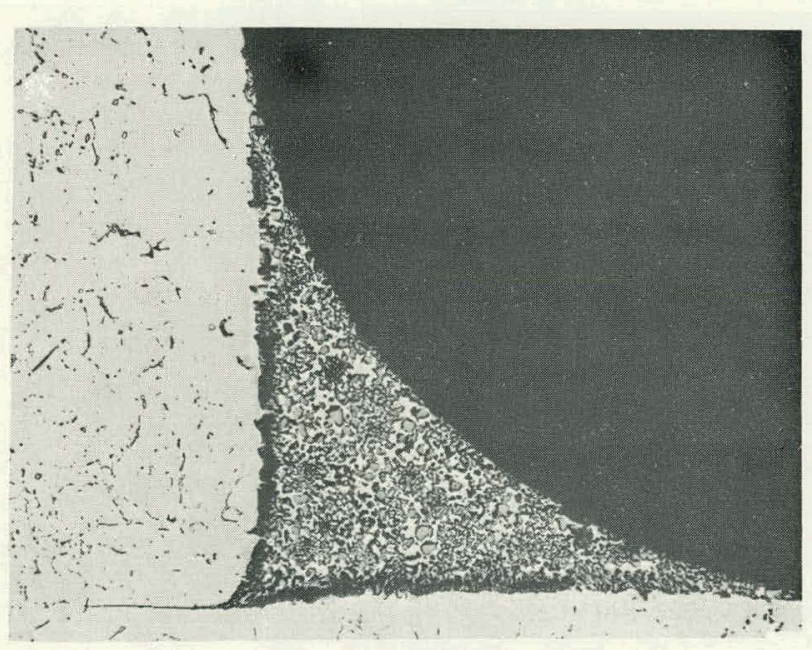

a. Effect of Best Atmosphere

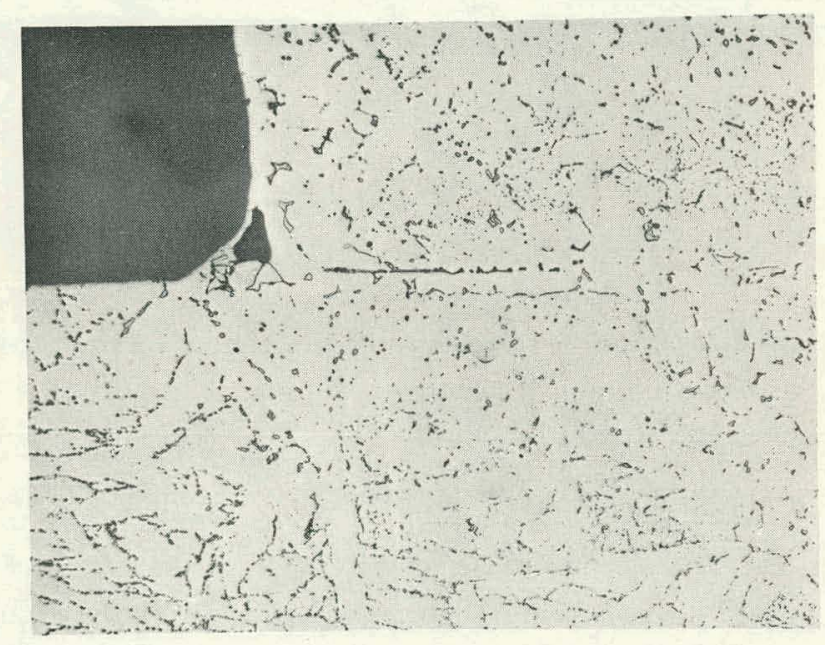

b. Effect of Good Atmosphere

Fig. 9 Effect of the Atmosphere upon the Angle of Contact between the Brazing Alloy and Zircaloy; Both Structures $40 X$

Under the influence of a poor atmosphere, the brazing alloy crept across plane surfaces either horizontally or vertically, as well as flowing into capillary joints. A solid film formed on the surface of the liquid brazing alloy, and gas, which was apparently a product of a reaction between the brazing alloy and the atmosphere, collected in bubbles under this film, as shown in Fig. 10.

Figure 11 shows another view of the same specimen in which the brazing alloy showed the influence of a good atmosphere. The better atmosphere was accomplished by a graphite crucible and Zircaloy 




FiQ. 10 Ettect of a Foor Atmosphere on the Rrazing Alloy

gettering strips which shielded the region better. In the pressure ranges obtained during this investigation, gas flow is of the molecular type, and line of sight shielding by a gettering material affords protection from gaseous contamination. Thus, the purity of the atmosphere can vary locally to a significant degree.

\section{Preplacing Brazing Alloy}

The Zircaloy-Be brazing alloy is brittle and has not been fabricated into foil or wire for convenient preplacing at brazed joints. Further, nuclear component dimensional requirements place strict limitations on the amount and distribution of the brazing alloy. The process must yield a high degree of confidence that all of the joints have been brazed, yet there cannot be excess brazing alloys which might restrict coolant passages or cover fuel alloy. Thus, a method of preplacing the brazing alloy was required which closely controlled the amount of brazing alloy and insured complete brazing.

The capillary flow of the brazing alloy throughout a network of numerous capillary joints from a few relatively large pieces of brazing alloy was the method of preplacing the brazing alloy employed in this investigation. 


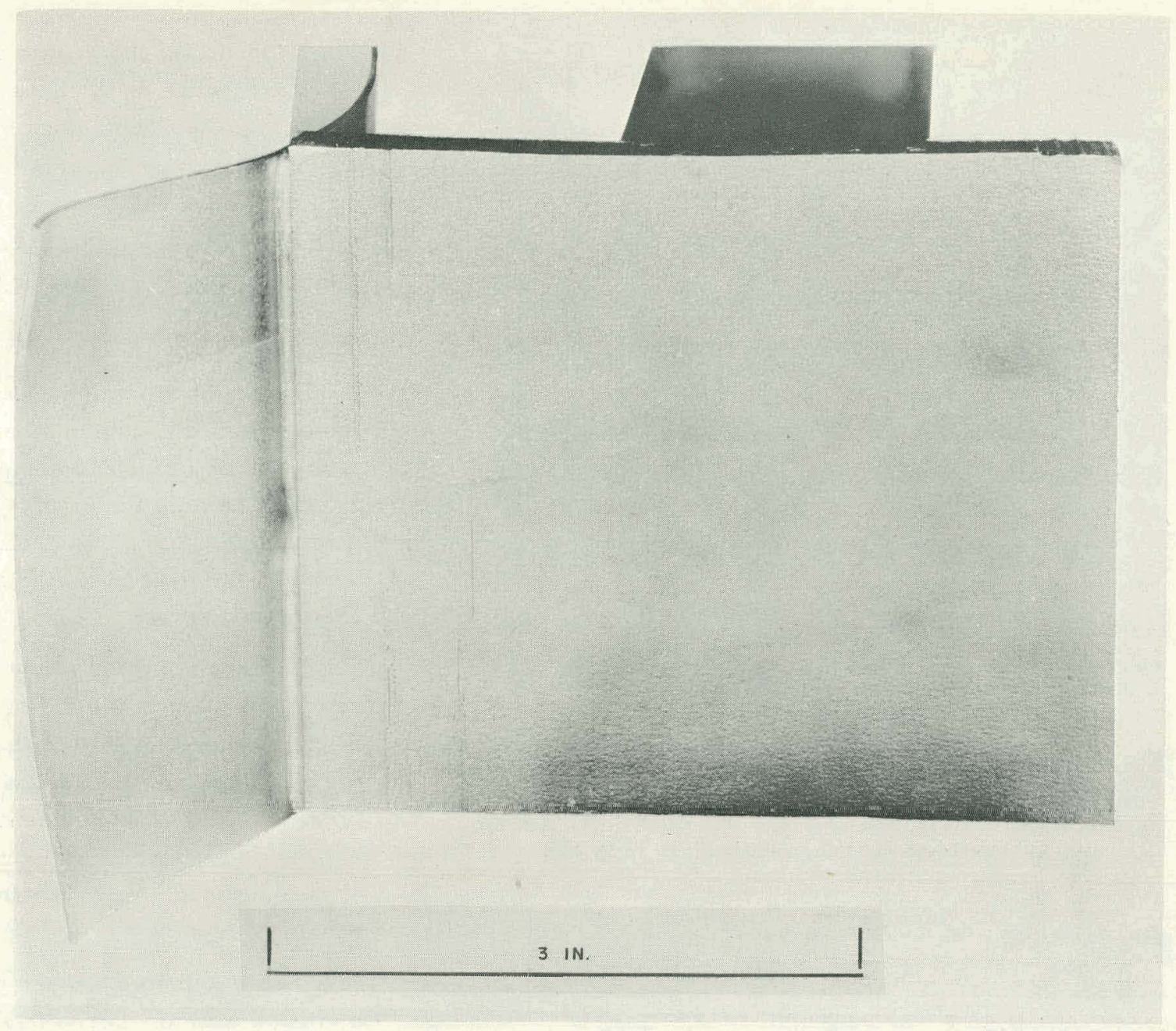

Fig. Il Effect of a Good Atmosphere on the Brazing Alloy

A measure of the capillarity of the brazing alloy was obtained by using specimens having $\mathrm{V}$ joints with $1 / 2^{\circ}$ included angle. Two bars $1-1 / 2 \times 9 / 32 \times 48$ in. were in contact along one side, while the other edges of the bars were separated by shims as shown in Fig. 12. The edges in contact were subjected to a clamping force because of the shrinkage when Zircaloy strips were welded to the edges of the bars. These specimens were suspended vertically in the brazing furnace. An excess of brazing alloy was provided at the bottom and the specimens were brazed.

After brazing, these specimens were sectioned at frequent intervals and examined metallographically to determine the maximum thickness of the joint which had filled with brazing alloy as a function of height above the source of the brazing alloy. The results are shown in Fig. 12 .

The capillarity of the brazing alloy caused it to flow $21 \mathrm{in}$. or more against the force of gravity in the thin portions of $1 / 2^{\circ}$ included angle $\mathrm{V}$ joints. With thicker joints, the brazing alloy rose to lesser heights. Considerable differences were noted between two duplicate specimens which were, however, brazed at different times with brazing alloys of the same nominal composition but from different lots. Both lots of brazing alloys were prepared by the Zircaloy-crucible melting procedure described in a previous section. The cause of the difference in behavior between the two specimens is not known. 


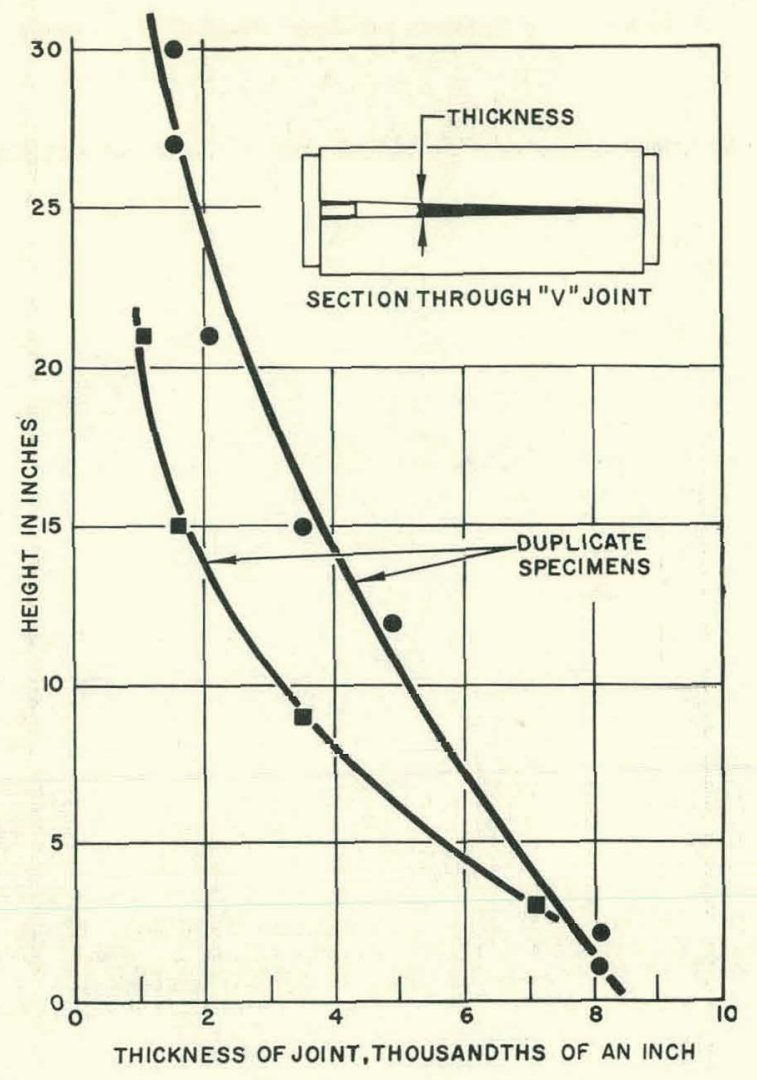

Fig. 12 Capillarity of the Brazing Alloy

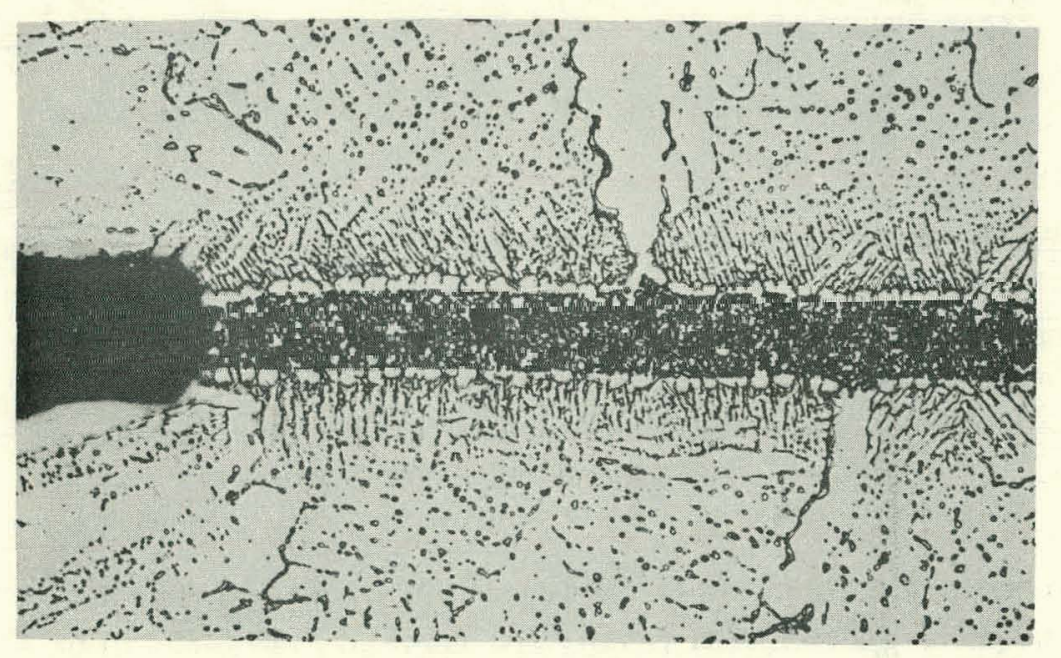

Fig. 13 Growth of Primary Zirconium-Rich Phase into Brazing Alloy; $250 x$
Evidence of the growth of a primary zirconium-rich phase into the liquid brazing alloy during brazing was noted during the metallographic examination of the $\mathrm{V}$-joint specimens. A possible mechanism for this phenomenon is that beryllium diffuses into the base material and depletes the brazing alloy of beryllium, thereby raising the liquidus temperature and causing the precipitation of a zirconium-rich phase. Figure 13 shows the primary zirconium-rich phase in a specimen which had been brazed $1 \mathrm{hr}$ at $1830^{\circ} \mathrm{F}$ and rapidly cooled.

The precipitation of the primary zirconium-rich phase during brazing might restrict the flow of the brazing alloy through thin joints. Therefore, a series of experiments was conducted to determine the minimum joint clearance ueeded for flow of brazing alloy.

Three specimens were prepared by fusion welding pairs of 1/2-in. wide strips along their edges so that smooth machined surfaces were forced together by the welding shrinkage. These specimens were brazed with brazing alloy at the ends of the slips in cunldal with the tiught. juint.

The brazing alloy did not flow into these joints more than approximately $0.020 \mathrm{in.}$ This distance was approximately the depth to which changes in the microstructure were observed due to diffusion of beryllium into solid Zircaloy during the brazing cycle.

The brazing alloy did not penetrate into joints tightly clamped by welding shrinkage, but this effect was almost entirely absent in the less tightly-clamped joints of the corrosion-tensile-specimen brazements. In these brazements there were joints 0.087-in. wide, with a nominal zero clearance lightly clamped during brazing which adjoined thicker capillary joints. Approximately 85 metallographic sections from these brazements were examined, and only one 
exhibited a small portion of a joint with unbrazed areas. This area appeared to be due to failure of the brazing alloy to penetrate a tight joint.

The reliability of capillary flow as a method of preplacing the brazing alloy was demonstrated with six specimens of the type shown in Fig. 1. These specimens contained a total of 48 vertical joints, each $8 \mathrm{in.} \mathrm{long.} \mathrm{All} \mathrm{of} \mathrm{these} \mathrm{joints} \mathrm{were} \mathrm{brazed} \mathrm{along} \mathrm{their} \mathrm{entire} \mathrm{length} \mathrm{as} \mathrm{evidenced} \mathrm{by}$ fillets of brazing alloy.

An upward capillary flow of the brazing alloy may not be sufficient to braze long assemblies. Therefore, the possibility of assisting the force of capillary action with the force of gravity was investigated by placing the brazing alloy at the top of an assembly. The assembly consisted of 15 dummy fuel plates inserted in two grooved side plates $22 \mathrm{in.} \mathrm{long.} \mathrm{The} \mathrm{details} \mathrm{of} \mathrm{the} \mathrm{upper} \mathrm{portion}$ of the assembly were designed to provide horizontal capillary joints approximately 0.010-in. thick along each grooved side plate. The horizontal capillary joints intersected all of the vertical joints between the dummy fuel plates and the grooved side plates. It was intended that the horizontal joints act as distributors which would feed brazing alloy to all of the vertical joints simultaneously from two pieces of brazing alloy.

The assembly was brazed in a vertical position with the brazing alloy at the top. The brazing alloy flowed down certain of the vertical joints and collected at the bottom where it completely filled several spaces between the plates. Other vertical joints did not braze.

More uniform distribution of the brazing alloy occurred when the capillary force opposed the force of gravity rather than when the force of gravity acted in the same general direction as the capillary force.

Tensile Strength of Brazed Joints

The study of the mechanical properties of brazements was limited to the determination of the tensile strength of simulated fuel plate to grooved side plate joints. The tensile specimens were machined from brazements of the type prepared for corrosion testing (Fig. 1). Twenty or more tensile specimens could be prepared from each brazement. A metallographic specimen was available immediately adjacent to the brazed joint of each tensile specimen and, approximately, 85 metallographic specimens representing 5 brazements were examined. The joint design and tensile specimen used are shown in Fig. 14.

The first lot of components produced did not meet the requirements for the design of the groove (Fig. 14), since the included angle of the dummy plates was approximately $36-1 / 2^{\circ}$ rather than $40^{\circ}$. Brazements were prepared from these components to study the effects of poor-fitting joints upon the tensile strength. A photomicrograph of a typical joint is shown in Fig. 15. The slresises in llie brazed joints could not be computed from the load on the specimen. Therefore, the tensile strengths reported were the maximum stresses on the gage length.

All poorly fitted joints fractured in the brazed joint during tensile testing with strengths ranging from 23,600 to $52,500 \mathrm{psi}$. The average strength was $37,000 \mathrm{psi}$, which was approximately $55.7 \%$ of the average strength of specimens having closely fitting joints and a similar brazing cycle.

Components which satisfied the requirements for the groove and plate dimensions were used for the three corrosion test brazements and the lensile tests to be described.

Twenty tensile specimens were fabricated from the slow-cooled brazement. (See the previous section on Corrosion Resistance of Zircaloy Brazements for details of brazing cycle.) These specimens were chosen to represent all eight joints and various distances from the source of the brazing alloy, and had strengths ranging from 32,900 to 73,700 psi, with the mean being 67,500 psi. However, these specimens may be divided into two classes: (1) the twelve specimens which fractured 


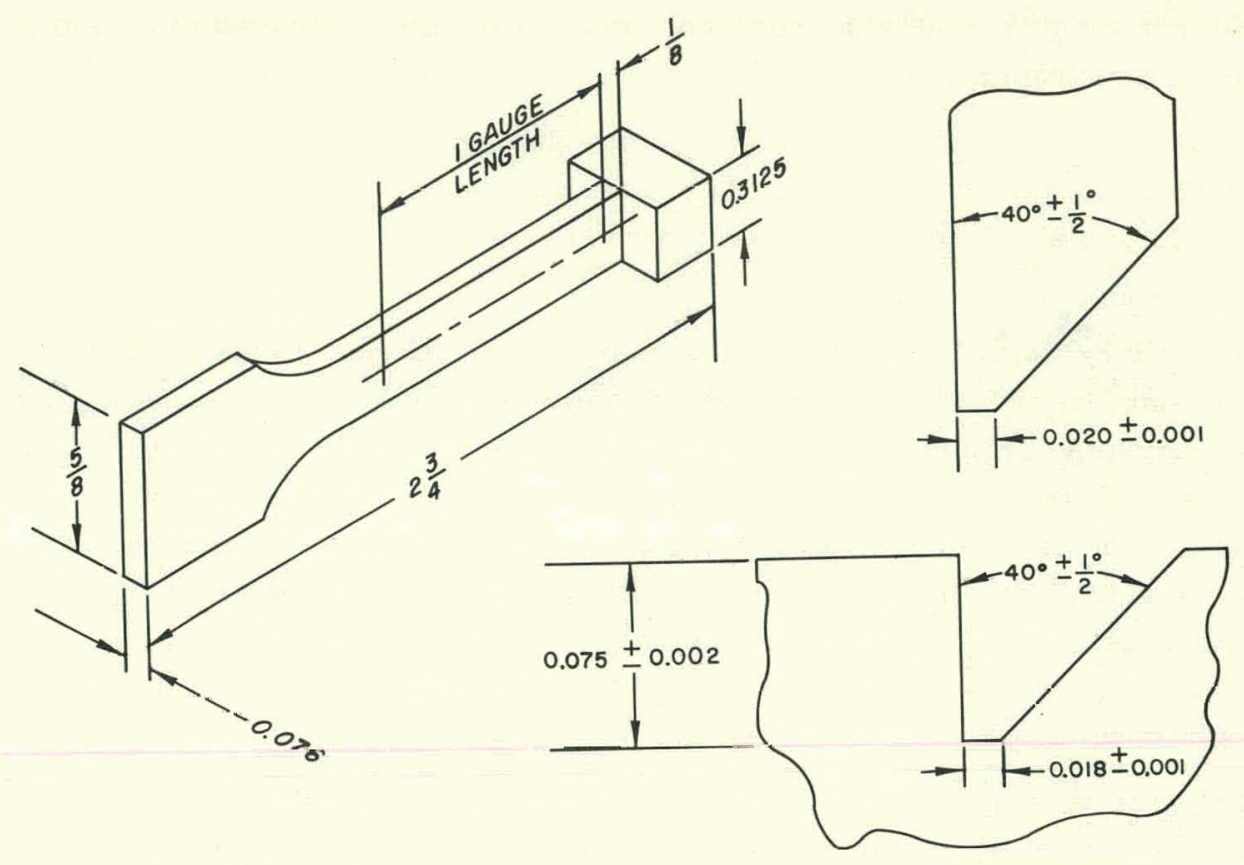

Fig. 14 Simulated Fuel Plate to Grooved Side Plate Joint and Tensile Specimen; All Dimensions in Inches

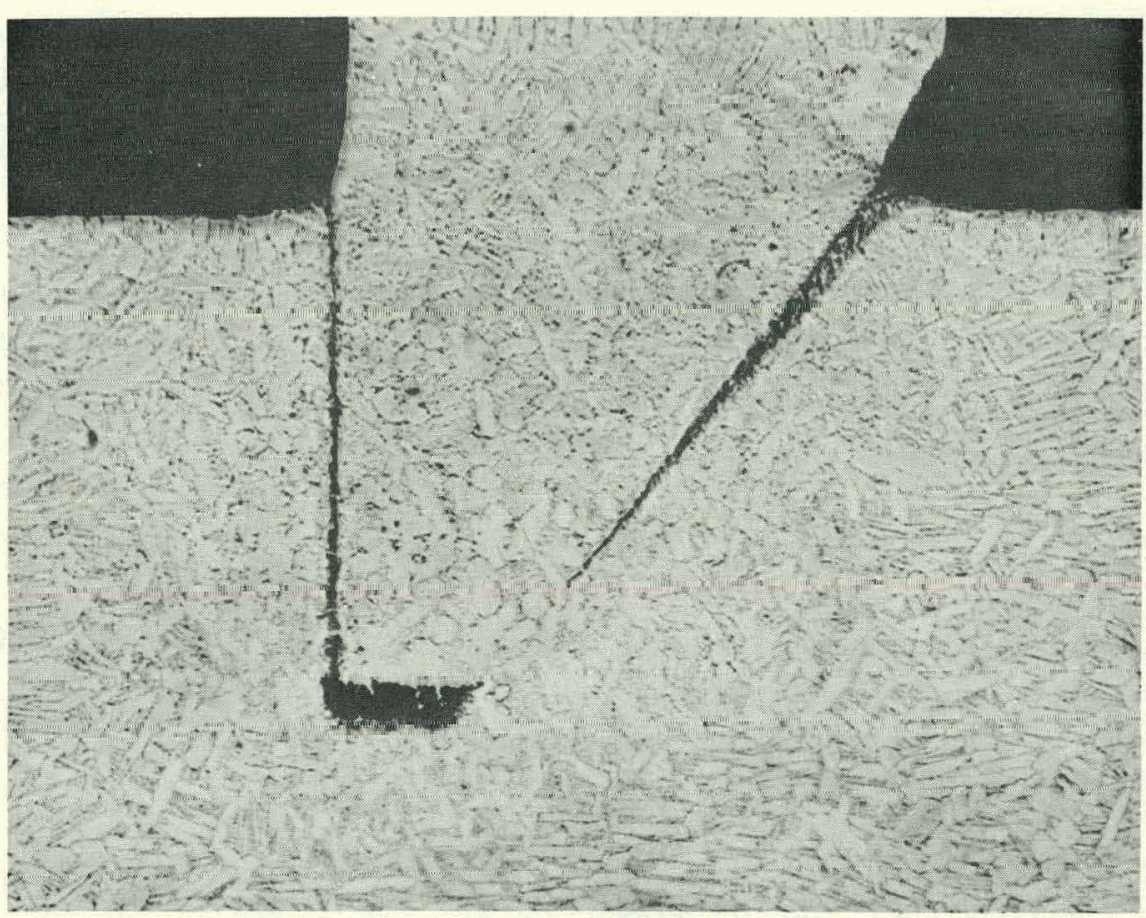

Fig. 15 Poorly Fitting Brazed Joint; 40X 
through or adjacent to the brazed joints and (2) the eight specimens which fractured in a ductile manner in the gage length. The results of the tensile tests are presented in Table III.

\section{TABLE III}

\section{TENSILE STRENGTHS OF BRAZED JOINTS}

\begin{tabular}{|c|c|c|c|c|c|c|}
\hline Condition & $\begin{array}{c}\text { No. } \\
\text { Specimens } \\
\text { Fractured } \\
\text { Away from } \\
\text { Brazed Joint }\end{array}$ & $\begin{array}{c}\text { No. } \\
\text { Specimens } \\
\text { Fractured } \\
\text { through or near } \\
\text { Brazed Joint }\end{array}$ & $\begin{array}{c}\text { Max } \\
\text { Tensile } \\
\text { Strength, } \\
\text { psi } \\
\end{array}$ & $\begin{array}{c}\text { Min } \\
\text { Tensile } \\
\text { Strength, } \\
\text { psi } \\
\end{array}$ & $\begin{array}{c}\text { Ave } \\
\text { Tensile } \\
\text { Strength, } \\
\text { psi } \\
\end{array}$ & $\begin{array}{c}\text { Ave } \\
\text { Elongation } \\
\text { in } 1 \text { In. Gage } \\
\text { Length, \% } \\
\end{array}$ \\
\hline Slow cooled & 8 & -- & 73,800 & 71,800 & 73,100 & 20 \\
\hline Slow cooled & -- & 12 & 72,500 & 32,900 & 61,900 & 2 \\
\hline Alpha annealed & 9 & -- & 82,000 & 80,600 & 81,300 & 20.4 \\
\hline Alpha annealed & - & 5 & 81,600 & 36,800 & 67,400 & 8.8 \\
\hline $\begin{array}{l}\text { Two-phase } \\
\text { annealed }\end{array}$ & 12 & -- & 82,600 & 80,500 & 81,400 & 19.0 \\
\hline $\begin{array}{r}\text { Two-phase } \\
\text { annealed }\end{array}$ & - & 2 & 82,700 & 79,900 & 81,300 & 6.0 \\
\hline
\end{tabular}

Metallographic examination of sections adjacent to these tensile specimens revealed that strength of joint was related to the microstructure of the brazed joint. Dispersion of the beryllium from the joint by diffusion, as shown in Fig. 16, promoted the higher strengths. The presence of a continuous or nearly continuous beryllium-rich phase in the joint, as shown in Fig. 17a and 17b, reduced the strength.

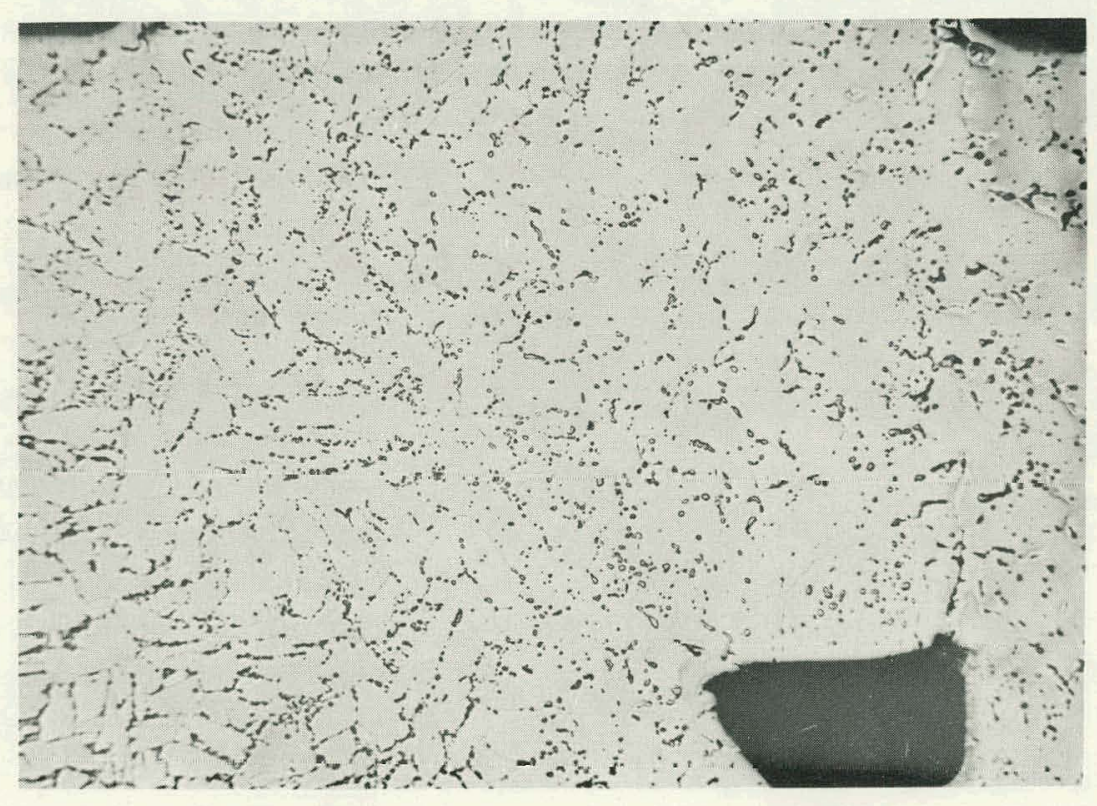

Fig. 16 High-Strength Brazed Joint; $40 \mathrm{X}$

A statistical analysis of the data by grooves (there were eight grooves per brazement) and height (distance from source of brazing alloy) showed no significant difference in strength at $90 \%$ probability level. Thus, the observed differences in tensile strength were apparently the result of 


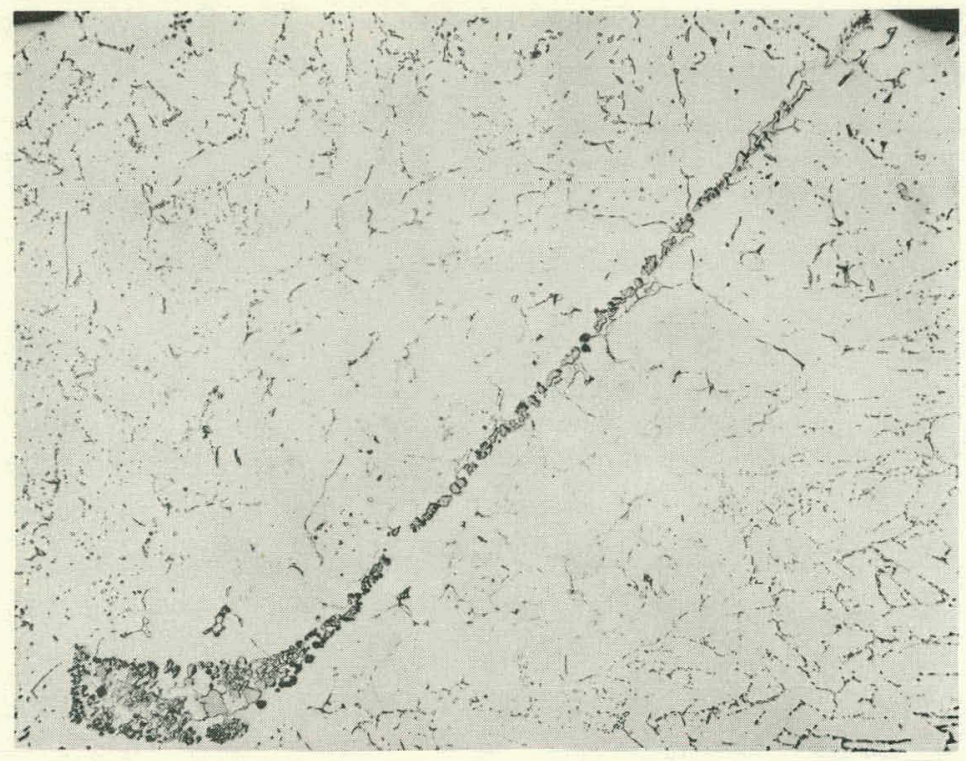

a. $40 x$

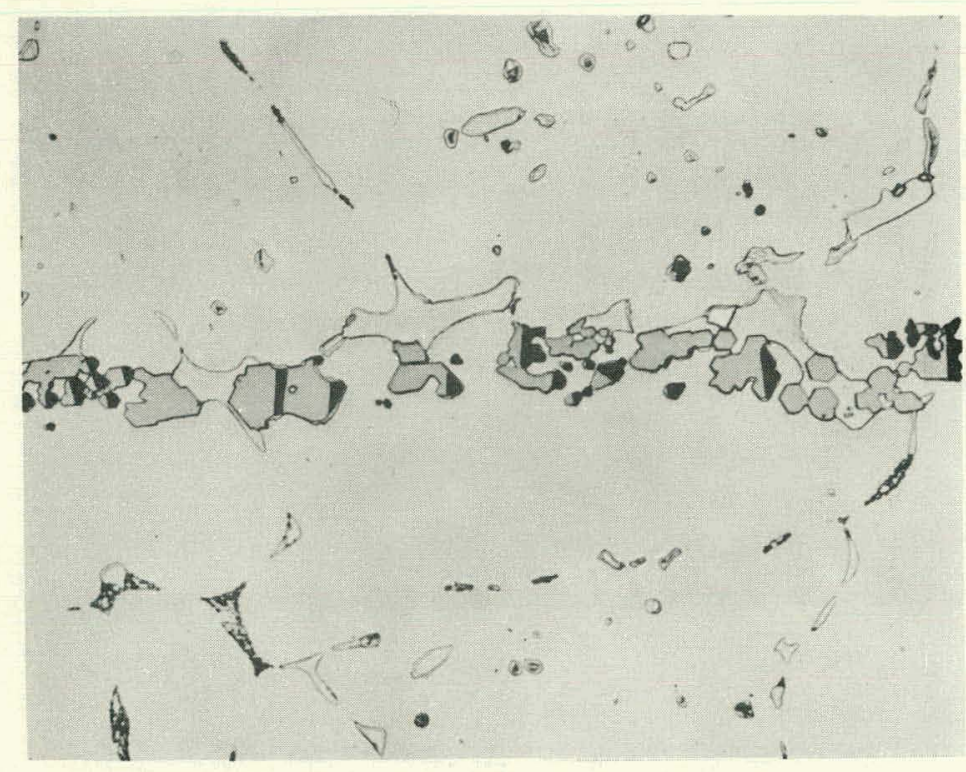

b. $250 x$ local, random differences in the joint strength rather than systematic differences between various grooves or the distance of flow of the brazing alloy.

The lower tensile strengths were, as previously mentioned, related to the presence of beryllium-rich phase in joint. The presence of the berylliumrich phase was attributed to minor local variations in the joint clearance. Increases in joint thickness would increase the tendency to retain the berylliumrich phase.

The alpha-annealed condition was intended to promote improved corrosion resistance; this cycle would also provide for somewhat greater diffusion of the beryllium. The tensile data in Table III show that a larger proportion of high strength joints occurred in the alpha-annealed specimens than in the slowly-cooled specimens.

The use of the two-phase annealing treatment was a further attempt to improve the tensile strength of the brazed joints by the dispersion of beryllium. The proportion of specimens which failed in a ductile manner away from the brazed joint was increased.

However, as noted in a previous section, the two-phase annealed treatment had a deleterious effect on corrosion resistance. This treatment would also be objectionable in that the increased opportunity for diffusion afforded by long time at high tomperature might permit significant amounts of us anium lo diffuse through the claduling.

Fig. 17 Low-Strength Brazed Joint

Dimensional Stability during Brazing

Nuclear core design places strict requirements on certain dimensional tolerances. The maintenance of these tolerances during brazing was anticipated to be a major problem for several reasons. Zircaloy and Zircaloy-uranium fuel alloys have little strength at the brazing temperatures. Also, zirconium-based alloys undergo a phase transformation accompanied by a volume change upon heating to the brazing temperature. Further, there are no alloys suitable for use as fixtures which would closely match the thermal expansion of Zircaloy. 
A preliminary experiment was conducted to determine the creep of a fuel element caused by a simulated brazing cycle. Strips were machined from rejected Zircaloy-clad, uranium-alloy fuel elements. These strips were supported horizontally as simple beams loaded only by their own weight during a simulated brazing cycle.

Strips supported on a 2 -in. span sagged less than 0.001 in., but strips supported on a 4-in. span sagged $0.037 \mathrm{in}$. during the brazing cycle. Thus, thin Zircaloy members must have maximum unsupported spans of less than 4 in.

Two experiments were performed to study the effect of the brazing operation on the dimensional tolerances of specimens whose cross sections resembled those of a nuclear core component having flat-plate fuel elements. A fixture to support the exterior of the specimens and a system for internal support (spacers) were employed. The dimensional tolerance of simulated water channels was of particular interest.

The fixture was constructed of type 304 stainless steel lined with molybdenum to prevent contact between Zircaloy and stainless steel. Pneumatic bellows inflated with helium were incorporated in the fixture to compensate for the difference in thermal expansion between stainless steel and Zircaloy. These bellows applied force through a rigid member to two adjacent sides of the specimen, forcing the specimen against the opposite sides of the fixtures. . The bellows were inflated and sealed at room temperature, so that gas pressure in the bellows at brazing temperature caused compressive stresses of approximately 20 psi in the dummy fuel elements during brazing.

Copper and steel spacers are used to support water channels of fuel assemblies during resis tance and fusion welding operations. However, both of these materials form eutectics with $Z$ ircaloy at the brazing temperature and cannot be used as spacers during brazing.

Since graphite is not soluble in zirconium at the brazing temperature, it is suitable for use as a spacer material in contact with Zircaloy. However, the conventional furm for spacers, a strip which has approximately the same dimensions as the channels, would be very fragile. Such a graphite spacer would be difficult or impossible to remove after brazing and could not be reused.

A method for the use of graphite spacers to support water channels is shown in Fig. 18. This method employed a multiplicity of small graphite spacers in each channel to effect spacing. The average thickness of the spacers was 0.0018 in. less than the average thickness of the water channels.

The width and length of the spacers, $7 / 16 \times 1-1 / 4$ in., were chosen as a compromise, since decreasing these dimensions would have made the spacers less fragile and more easily removed, and increasing these dimensions would have reduced the number of spacers required for a given degree of support.

The graphite spacers were inserted into the channels, positioned within the channels, and removed from the brazed assembly with the aid of a refractory metal retainer, whose thickness and width was intended to be sufficiently less than that of channel to allow insertion and removal without iulerference. The spacere fit in slots in the retainers. Strips of a molybdenum alloy $10.5 \% \mathrm{Ti}-$ balance Mol $0.015 \times 2.25 \mathrm{in}$. were used in $0.060 \times 2-1 / 2 \mathrm{in}$. channels. The maximum unsupported span was approximately $1-1 / 81$.

The specimens had a $3 \times 3$ in. cross section and consisted of an assembly of twenty-one 7 -in. long dummy fuel plates inserted into grooved side plates. A Zircaloy base was provided to support the hrazing alloy and provide a capillary joint for the horizontal distribution of the brazing alloy to the base of each of the 42 grooves.

In the first experiment, brazing did not occur because of an error in furnace temperature. However, the temperature of the assembly reached approximately $1760^{\circ} \mathrm{F}$, as indicated by incipient 


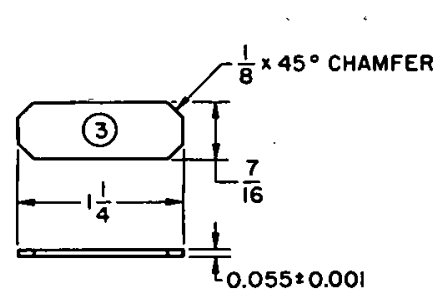

DETAIL A

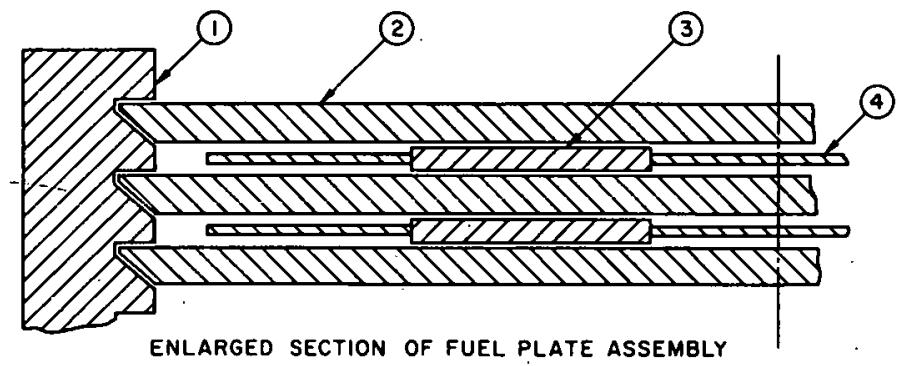

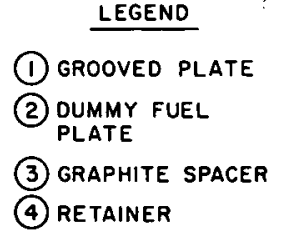

ENLARGED SECTION OF FUEL PLATE ASSEMBLY

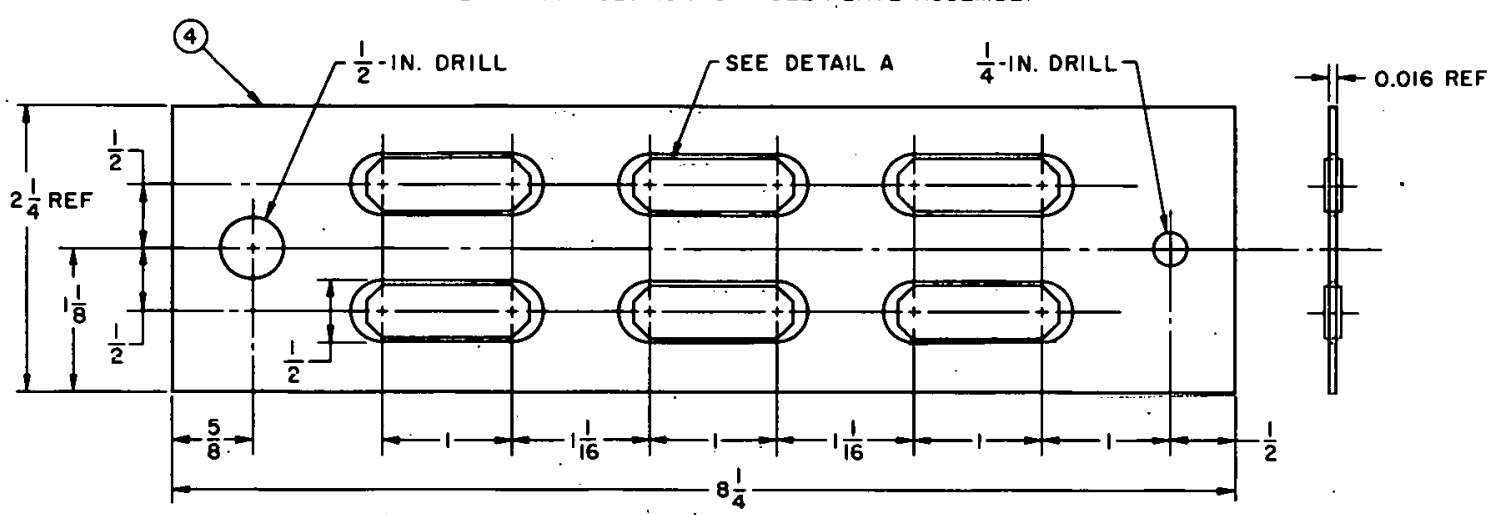

Fig. 18 Spacers for Coolont Channel Support during Brazing: All Dimensions in Inches

melting of the brazing alloy. With the side plates tightly clamped after the brazing cycle, the spacers were easily removed with only $2 \%$ breakage. There was no measurable reduction of average thickness of the spacers resulting from wear. Thus, the spacers were suitable for reusc.

The assembly had a standard deviation of channel thickness of 0.00137 in. after the brazing cycle. This variation in channel thickness was comparable to variations obtained in fusion welded assemblies, despite the excessive bowing $(0.005$ to 0.007 in. across the $2-1 / 2$ in. width) of the plates prior to brazing. Thus, this method of support during brazing had eliminater much of the bowing of the dummy fuel plates.

During the second experiment, the vacuum furnace retort collapsed on the fixture under aliuvspher'tc pressure and caused gross distortion of the fixture and assembly. This prevented a study of the effectiveness of the spacer system. However, all 42 joịnts between side plates and dummy fuel plates were brazed throughout their length.

\section{ACKNOWLEDGEMENTS}

The writer wishes to take this opportunity to thank R. E. Drocgkamp, R. M. Stackhouse, and A. B. 'Thomas of Bettis Plant for their valuable assistancc. Special thanks are extended to R. J. Mautino for the performance of much of the experimental work.

\section{REFERENCES}

1. R. M. Necheles and H. Schwartzbart, "Corrnsion Resistant Braging Mlloya for Zir salory," AECU-2826 (July 1957).

2. D. W. White and J. E. Burke (eds.), The Metal Beryllium, (Cleveland: American Society for Metals, 1955), pp 620-639.

3. D. Lustual and F. Kerze, Jr. (ed.), Metallurgy of Zirconium, (New York: McGraw-Hill Book Co., 1955) p 634.

4. L. S. Rubenstein, J. G. Goodwin, and F. L. Shubert, "Relationship of Cooling Rate to the Corrosion Resistance of Zircaloy-2," Bettis Technical Review, WAPD-BT-10 (December 1958), pp 23-30. 